\title{
Nacionalnopreporodni rad mons. Bože Milanovića u tršćanskom razdoblju 1922. - 1945.
}

\author{
Izvorni znanstveni rad | Original scientific paper \\ UDK 262.14 Milanović, B."1922/1945 \\ Primljeno: 3. XI. 2010.
}

\begin{abstract}
Izvadak
Svećenik Božo Milanović, po mnogima "najznamenitiji i najosebujniji" Istranin XX. stoljeća, pod pritiskom fašističkog terora godine 1922. napušta Istru i sklanja se u susjedni Trst, uvjeren kako će u velikom gradu biti manje na oku režimu te da će uz redovit pastoralan rad moći razvijati nacionalni, kulturno-prosvjetni, pa i politički rad. U dugom tršćanskom razdoblju koje će potrajati sve do završetka Drugog svjetskog rata, s prekidom od 1941. do 1943., kada je bio konfiniran u Bergamo, Milanović je, otvoren za suradnju i s idejnosvjetonazorskim protivnicima (liberalima), razvio bogatu izdavačku djelatnost preko Društva sv. Mohora za Istru, a kroz list Pučki prijatelj branio je hrvatske i slovenske političke interese. Po završetku rata prihvaća suradnju s vodstvom Narodnooslobodilačkog pokreta uvjeren kako je NOP jedina snaga koja može ostvariti san generacija istarskih hrvatskih političara, a to je bio i njegov san, sjedinjenje Istre s Hrvatskom.
\end{abstract}

\section{Sintesi}

Il sacerdote Božo Milanović, che molti reputano l'istriano "più celebre e singolare" del XX secolo, sotto la pressione del terrore fascista del 1922, abbandona l'Istria e si sposta nella vicina Trieste, convinto che in una città grande sarebbe stato meno osservato dal regime e che accanto alla regolate attività pastorale avrebbe potuto svolgere compiti di carattere nazionale, culturale, educativo e politico. Durante il lungo periodo triestino, protrattosi fino alla fine della Seconda guerra mondiale, con un intervallo dal 1941 al 1943 dovuto al suo confino a Bergamo, Milanović, aperto anche alla collaborazione con gli oppositori alle sue idee e ai suoi punti di vista (i liberali), sviluppa un'attività editoriale molto ricca grazie al Sodalizio San Ermacora per l'Istria, mentre attraverso il giornale Pučki prijatelj difende gli interessi politici croati e sloveni. Con la fine della guerra accetta la collaborazione con il 
comando del Movimento popolare di liberazione, convinto della sua capacità di realizzare il sogno di generazioni di politici istriani e croati, che anch'egli condivise, l'unificazione dell'Istria con la Croazia.

Ključne riječi: Božo Milanović, tršćansko razdoblje, Društvo sv. Mohora za Istru, izdavačka djelatnost, politički rad, unutarcrkvene prilike, NOP, suradnja.

Parole chiave: Božo Milanović, periodo triestino, Sodalizio San Ermacora per l'Istria, attività editoriale, opera politica, situazione interclericale, MPL, collaborazione.

\section{Uvod}

Izložen stalnim pritiscima i prijetnjama, uhićenjima i saslušavanjima, prijetnjama fizičkom likvidacijom, od samog početka talijanske okupacije Istre u studenom 1918. godine, da bi sve kulminiralo na početku 1922. kad su ga, po povratku iz Trsta, posjetila dvojica karabinjera i priopćila mu da fašisti iz 18 raznih istarskih mjesta kane doći u Kringu i ubiti ga, Milanović se odlučio skloniti u Trst, uvjeren kako će njegov kulturno-prosvjetni i nacionalno-politički rad manje biti primjetan u velikom Trstu nego u maloj Kringi. Da se ne radi o ispraznim prijetnjama uvjerila ga je napomena jednog posjetitelja kako će, u slučaju da vjernici Kringe ustanu u obranu svog mještanina i svog župnika, spaliti cijelo selo. Vremena za odgađanje odlaska iz Kringe više nije bilo. Dilemu otići u Jugoslaviju ili se skloniti negdje bliže brzo je riješio. Koliko god ga je odlazak u Jugoslaviju privlačio, tamo bi bio "među braćom", više ga je odbijalo to što bi u tom slučaju bio daleko od rodne Istre i tko zna kad bi se mogao vratiti k svojima u zavičaj. Zato je odlučio utočište potražiti negdje bliže. O svemu je obavijestio biskupa Angela Bartolomasija, a ovaj ga je 7. veljače 1922., na nagovor tršćanskog kanonika Ivana Mandića, imenovao župnim pomoćnikom u župi sv. Ivana u tršćanskom predgrađu Guardiella, župi nastanjenoj pretežno slovenskim vjernicima. ${ }^{1}$ Dolaskom u Trst počinje novo razdoblje u životu i djelovanju Bože Milanovića.

\section{U potrazi za modelom djelovanja}

U Trstu se Milanović, u mirnijem ozračju, bez straha da će svaki čas netko pokucati na vrata i optužiti ga za protudržavni rad ili projugoslavensku propagandu, mogao intenzivnije posvetiti nacionalno-političkom i kulturnom radu kao važnim dijelovima pastoralnog rada. Na njegovo široko polje djelovanja, dobrim dijelom izvan uskih crkveno-vjerskih okvira, sa simpatijama je gledao

1 Božo Milanović, Moje uspomene (1900.-1976.), Pazin 1976., 55. 
župnik Franjo Sali, dobroćudni i već vremešni Slovenac. ${ }^{2}$ Bez njegova razumijevanja i podrške mladi kapelan bi sigurno ostao zatočenik tradicionalnog, u crkvene okvire zatvorenog, pastoralnog rada. U početku se sav Milanovićev nacionalno-politički i kulturno-prosvjetni rad odvijao unutar istarskog Pododbora slovenskog političkog društva Edinost te je bio usmjeren na brigu za uredno poslovanje, redovno izlaženje i slanje pretplatnicima lista Pučki prijatelj (dalje: PP). Priklanjanje brojnijim i politički organiziranijim Slovencima bilo je uvjetovano realnom procjenom da hrvatska nacionalna zajednica u Trstu nije ni brojčano, ni intelektualno, a niti materijalno na razini na kojoj bi sama mogla stvoriti svoju političku organizaciju, a da je i mogla, bilo je upitno bi li dobila odobrenje vlasti.

Pristajanje uz Slovence zbog zajedničkih interesa i organiziranijeg nastupa prema protuslavenskoj talijanskoj politici nije nikada dovelo do zanemarivanja istarske situacije, odnosno utapanja istarskih hrvatskih političara u slovensku organizaciju Edinost. Dokaz tome je i osnivanje Pododbora Edinosti za Istru. ${ }^{3}$

Idejno-svjetonazorske podjele i sukobi između narodno-liberalne i kršćansko-socijalne struje u slovenskom društvu, a koje će dovesti i do organizacijsko-političkih podjela, već u predratnom vremenu utjecale su na iste podjele kod istarskih Hrvata, među kojima te podjele ipak nisu dovele i do političkih, formalno-organizacijskih podjela. U novim prilikama predratne podjele među Slovencima nastavile su se i snažno su utjecale na jednake podjele među istarskim Hrvatima u Trstu. To, dakako, ne znači da je samo “izvanjski”, isključivo slovenski utjecaj, utjecao na te podjele. Međutim, ne može se poreći da je taj utjecaj pospješio njihovu artikulaciju.

Kad je došao u Trst, Milanović se s nekolicinom svojih suradnika uključio u rad Edinosti kao jedine "slavenske" političke organizacije u Trstu. Njezina liberalna orijentacija nije ga smetala jer je vjerovao da je rad na obrani narodnih prava dovoljno jaka kohezivna snaga u prevladavanju idejnih razlika. Jednako tako, vodstvu Edinosti na čelu s Josipom Wilfanom nije smetala Milanovićeva "klerikalna” prošlost istaknutog pristaše Mahnićeva intranzigentnog katolicizma. ${ }^{4}$ Aktualizirana predratna "dioba duhova" među Slovencima nužno je dovela do jednake diobe i među istarskim i tršćanskim Hrvatima. Protiv pokušaja liberalne Edinosti da preuzme vodstvo i legitimira

\footnotetext{
$\mathrm{Na}$ ist. $\mathrm{mj}$.

3 Isti, Istra u 20. stoljeću, 1. knjiga, Pazin 1992., 127. (dalje: Istra u 20. stoljeću I); isti, Moje uspomene, 53.

4 Isti, Istra u 20. stoljeću I, 130-131.
} 
se kao jedini predstavnik Hrvata i Slovenaca ne samo u Trstu, nego i u Istri i Gorici, ustala je snažna kršćansko-socijalna grupa u Gorici na čelu sa svećenikom i zastupnikom u talijanskom parlamentu u Rimu Virgilom Ščekom. Oni su smatrali da imaju bolje pretpostavke za organiziranje i napredak Slovenaca u Julijskoj krajini. Međutim, od toga su imali malo koristi jer je kod istarskih Hrvata i kod jugoslavenske vlade u Beogradu, od koje je stizala novčana potpora, autoritet neupitnog predstavnika "slavenske manjine” u Italiji uživala Edinost. ${ }^{5}$

Virgil Šček, u želji da svoju kršćansko-socijalnu goričku grupu oslobodi tutorstva tršćanske Edinosti te da izbori ravnopravnost i politički subjektivitet i legalitet Goričana, počeo je s napadima na Josipa Wilfana. Ščekov pokušaj s osnivanjem kršćansko-socijalne organizacije u Gorici bio je kratkog daha, organizacija se ubrzo raspala. Puno više uspjeha imao je s pokretanjem novina Mali List koji je dobro bio prihvaćen u Trstu i sjevernoj Istri. Velik utjecaj imalo je i Ljudsko tajništvo koje je u Gorici otvorio Ščekov pristaša, pravnik Josip Bitežnik. On je, radeći u Tajništvu kao pravnik, davao ljudima besplatne pravne savjete, pisao im molbe i žalbe, te je tako vršio propagandu i pridobivao pristaše za kršćansko-socijalnu grupu. ${ }^{6}$

Sve to utjecalo je na istarski Pododbor Edinosti. O tom utjecaju Milanović piše: "Da je naše središte ostalo gdjegod u Istri, ne bismo se bili možda mnogo brigali za te prilike, ali u Trstu nismo mogli izbjeći njihovu uplivu. Premda smo osnovali svoj politički 'Pododbor Edinosti za Istru' zato da radimo u njemu samostalno, ipak su valovi stvaralačke borbe među Slovencima udarali neprestano o Istrane te su nas dijelili sve više po načelnoj opredijeljenosti i osobnom prijateljstvu.” ${ }^{7}$ Drugim riječima, i Istrani su se morali odrediti prema slovenskim idejno-političkim podjelama, a to je ipso facto izazvalo iste podjele i među njima samima. Opredjeljivanje Istrana za Edinost ili za goričku grupu imalo je utoliko veće značenje što su oni predstavljali određen jezičac na vagi, iako se to u tom trenutku nije toliko primjećivalo. Naime, ako bi pristali uz Edinost onda bi se ona mogla predstavljati, a to joj je bio i cilj, kao zastupnik Hrvata i Slovenaca u Italiji jer je imala nešto simpatizera i u Gorici. U slučaju podrške goričkoj grupi, mogla bi se ona smatrati predstavnikom "slavenske manjine" u Italiji. ${ }^{8}$ 
Premda su Milanović i krug oko PP-a odgajani u duhu Mahnićeva borbenog katolicizma, karakterističnog i po tome što je tražio strogo distanciranje od onih koji javno ne prihvaćaju katolička načela kao normu društvenog djelovanja, ipak je u njima, u dubini, živ bio i Dobrilin duh narodne sloge. Zato su Milanović osobno, a i PP kao list, izbjegavali teme koje bi mogle unijeti razdor u političko djelovanje istarskih Hrvata. U kontekstu navedenog možemo razumjeti Milanovićevo početno uspješno balansiranje između dviju suprotstavljenih slovenskih grupa, tj. nastojanje da se ne prikloni ni jednoj ni drugoj. Na poziv Virgila Ščeka da se grupa oko PP-a pridruži goričkoj kršćansko-socijalnoj grupi Milanović se nije obazirao, što je dovelo do zahlađenja odnosa između ove dvojice poznanika još sa zajedničkog studija u Gorici. ${ }^{9}$

Jednako je tako odbio Wilfanovu ponudu da će pomoći Tiskovno društvo u Pazinu sa 50.000 lira kao nadoknadu za gubitak tiskare te da će tiskari Edinosti isplatiti dug PP-a od 20.000 lira ako se Tiskovno društvo pridruži tršćanskoj liberalnoj skupini oko Edinosti. ${ }^{10}$ Nezadovoljan Milanovićevim odbijanjem, Wilfan je u Trst pozvao pulskog pravnika i političara Mirka Vratovića i povjerio mu zadaću da od liberalne istarske grupe osnuje novi pododbor i da ga pripoji političkom društvu Edinost. ${ }^{11}$

Netrpeljivost između "klerikalaca" i "liberala" postajala je sve veća pa je svaki zajednički rad i javni nastup postao nemoguć. Bilo je jasno da neiživljene predratne podjele i predrasude između dviju navedenih grupa ne može zatomiti ni Milanovićeva vještina kompromisa. Unatoč svemu, sam je Milanović vjerovao u mogućnost dogovora. Kao predsjednik sazvao je za 10. srpnja 1922. u Kozini skupštinu Pododbora Edinosti za Istru. Na skupštini je bilo prisutno 80-ak članova. Jedno od prijepornih pitanja na skupštini, već od ranije prisutno u političkom životu Hrvata i Slovenaca u Julijskoj krajini, bilo je osnivanje posebnih odbora za Istru, Goricu i Trst, koji bi bili potpuno samostalni u svom radu, s tim da bi zajedničko Narodno vijeće koordiniralo rad triju pododbora. Članovi i pristaše Edinosti i dalje su smatrali kako njihova organizacija uživa povjerenje većine Hrvata i Slovenaca u Italiji te da joj pripada vodeća uloga. ${ }^{12}$

U naelektriziranoj atmosferi punoj međusobnih optužbi i upadica Mila-

\footnotetext{
$9 \quad \mathrm{Na}$ ist. mj.

10 Isto, 137.

11 Isti, Moje uspomene, 58-59.

12 Isto, 60-61.
} 
noviću je teško bilo usmjeriti rad skupštine prema mirnim vodama. Želeći osigurati mir, toliko je lupao po staklenoj čaši da ju je razbio. Opći je dojam bio kako je liberalna skupina agresivnija u svojim zahtjevima. Iako su i sami doveli na skupštinu neke slovenske liberale, smetao im je govor Engelberta Besednjaka, jednog od prvaka goričke "klerikalne” grupe. Za vrijeme izlaganja prekidali su ga upadicama da je sve što predlaže obična demagogija. Uliks Stanger, pravnik i političar liberalnog usmjerenja, vrijeđao je pristaše PP-a. Usvojen je njegov prijedlog da se kao nevažeće odbace punomoći seljaka koji nisu mogli doći na skupštinu, nakon čega je nekolicina seljaka demonstrativno napustila skupštinu.

Sve izgledniji prekid rada skupštine spasio je Milanović prijedlogom da se s radom nastavi poslije objeda i popodnevnog odmora. U mirnijem popodnevnom ozračju prihvaćeno je kompromisno rješenje: u Pododbor od 24 člana ući će i "liberalci” i "klerikalci”. Očekivanje da bi tako formiran odbor mogao krenuti u izglađivanje sporova i spriječiti formalne podjele nestalo je u trenutku kad je Uliks Stanger najavio da će njegova "liberalna" grupa izdavati svoj tjednik. Uzaludno je bilo Milanovićevo dokazivanje kako Istra nema ni materijalnih ni intelektualnih pretpostavki za održavanje dva lista. U cilju kompromisa predložio je novom (budućem) predsjedniku Pododbora da u svakom idućem broju PP-a slobodno precrta ono što mu se ne sviđa i da to neće biti tiskano. ${ }^{13}$ Zadnji Milanovićev pokušaj "mirenja” također je propao. Predlagao je da na sjednici Pododbora sazvanoj za 25. srpnja 1922. novoizabrani članovi Pododbora između sebe izaberu predsjednika. Međutim, liberali su se sastali 17. srpnja i u Pododbor izabrali samo svoje pristaše, koji su za predsjednika izabrali Mirka Vratovića. ${ }^{14}$

Znak novog zaoštravanja bila je obavijest iz tiskare Edinosti poslana Milanoviću 29. kolovoza 1922., dva dana prije izlaska PP-a, da će tiskanje PP-a biti obustavljeno ako im u roku od dva dana ne isplati dug od 20.000 lira. $\mathrm{Na}$ čuđenje zašto je tiskara zatražila podmirivanje duga kad je znala da on u tako kratkom roku neće moći biti podmiren, odgovor je ubrzo stigao. Umjesto PP-a počeo je izlaziti tjednik liberalne grupe Stara Naša Sloga, tiskan u tiskari Edinosti. Koliko god je ovakve postupke idejnih protivnika teško proživljavao, ne samo zbog odnosa prema njemu, nego još više zbog nepoštivanja institucije Tiskovnog društva u Pazinu i PP-a, Milanović se nije predavao,

13 Isto, 61.; "Istarska politička skupština u Kozini”, PP, god. XXIII, br. 28 (Trst, 13. VII. 1922.), 1.; "Novi sastanci i skupštine”, PP, god. XXIII, br. 29 (Trst, 20. VII. 1922.), 1.; “Odgovor listu 'Edinost'. I mi velimo: Ne tako braćo!", PP, god. XXIII, br. 30 (Trst, 27. VII. 1922.), 1.

14 Milanović, Moje uspomene, 62. 
niti ga je obuzimala malodušnost. Otišao je do vlasnika najjeftinije tršćanske tiskare i dogovorio se s njime o tiskanju PP-a. Tako je PP već 7. rujna opet ugledao svjetlo dana. ${ }^{15}$

Sami liberali su uvidjeli kontraproduktivnost svojih poteza i za njih same, pa su preko Srećka Jopa, namještenika u PP-u, poručili Milanoviću da su spremni obustaviti izdavanje Stare Naše Sloge ako on obustavi izlaženje PP-a. U tom bi slučaju oni izdavali politički list, a Milanovićeva bi grupa mogla izdavati gospodarsko-kulturni list.

Uvjeren da je u postojećoj situaciji jedino rješenje povratak politici narodne sloge, Milanović je ponudu prihvatio, uvjeren da i druga strana tako razmišlja. Na temelju sporazuma o suradnji na početku 1923. pojavili su se list Istarska Riječ, stvarno u rukama liberala, a formalno zajedničko glasilo obiju grupa, i Istra kao kulturno-gospodarski list, pod uredničkom palicom Milanovića i "klerikalaca”. ${ }^{16}$ Sporazum je kratko trajao - već nakon prvog broja Mirko Vratović, predsjednik liberalnog Pododbora Edinosti, izjavio je da se ne slaže s koncepcijom Istre i da zbog toga otkazuje sporazum. Razlozi otkazivanja sporazuma nisu bili koncepcijske, nego financijske naravi. Izdavači Istarske Riječi obvezali su se isplatiti dug PP-a od 20.000 lira i pružiti potporu novopokrenutoj Istri, ${ }^{17}$ a otkazivanjem sporazuma otpale su i preuzete obveze.

Svjestan svog položaja u odnosu na ideološke i političke protivnike, koje, usput, nikad nije doživljavao kao neprijatelje, Milanović je, radi smanjivanja troškova sam preuzeo uređivanje Istre. Smatrao je da bi, bez obzira na tešku financijsku situaciju, obustavljanje izlaženja lista značilo kapitulaciju kršćansko-socijalne političke orijentacije. Držeći u rukama Pododbor Edinosti za Istru, liberali su se predstavljali kao jedini politički predstavnici istarskih Hrvata i kao takvi uživali su materijalnu podršku političkog fonda Edinosti. ${ }^{18}$ Iako marginalizirana, kršćansko-socijalna grupa je nastavila s radom dajući svoj ne tako zanemariv doprinos borbi istarskih Hrvata, u prvom redu na kulturno-prosvjetnom planu.

Umjesto naziva kršćansko-socijalna, odnosno, demokratsko-liberalna stranka upotrebljavao se naziv "struja” ili jednostavno "mi” i "vi”, ili oni s pejorativnim prizvukom "klerikalci”, odnosno, "liberalci”. I dok su istarski

\footnotetext{
15 Isto, 63.; "Nova istarska nesloga”, PP, god. XXIII, br. 35 (Trst, 7. IX. 1922.), 1.

16 Milanović, Moje uspomene, 64.

17 Isti, Istra u 20. stoljeću I, 142 .

$18 \mathrm{Na}$ ist. mj.
} 
"klerikalci” postali saveznici svojih istomišljenika goričke narodne, kršćanskosocijalne grupe, liberali su se priklonili Wilfanovoj demokratsko-liberalnoj Edinosti. ${ }^{19}$

Potrebu nazočnosti kršćansko-socijalne ideje i političke prakse na istarskoj društveno-političkoj sceni Milanović vidi u njezinim filozofsko-antropoloških temeljima, koji su, ističe on, superiorni onim liberalnim. Samo kršćanski temelji mogu biti garancija ozbiljnog i predanog rada za narod i njegove interese, dok liberalni agnosticizam i ateizam, sve do antiteizma, nužno za posljedicu imaju “plitak i besplodan” javni rad. K tome, ističe Milanović, rad narodno-liberalne grupe protivan je kršćanskim tradicijama istarskih Hrvata. Zbog svjetonazorskih razlika nije vjerovao u mogućnost iskrene i trajne suradnje između ovih dviju grupa, preciznije, da je narodno-liberalna struja kadra uvažiti svećenike kao jedinu hrvatsku inteligenciju koja je ostala u Istri nakon talijanske okupacije te prihvatiti i poduprijeti njihove inicijative. U borbi za narodni opstanak, zaključuje Milanović, liberali zanemaruju ili se čak protive "narodnocrkvenoj politici” (briga za svećenički podmladak, očuvanje hrvatskog jezika u liturgiji, vjeronauku, propovijedima, crkvenom pjevanju, izdavanje molitvenika na hrvatskom jeziku). Zato njihovom nacionalnopreporodnom djelovanju nedostaje širina koju može ostvariti kršćansko-socijalna grupa. ${ }^{20}$

Tako su idejne razlike dobile svoje "prirodne" organizacijske oblike i među istarskim Hrvatima. Ti oblici nisu poprimili stranačku formu pa su i suvremenici umjesto naziva stranka upotrebljavali naziv struja ili grupa.

\section{Rad kroz Društvo sv. Mohora za Istru}

Čim je uspostavljena talijanska vlast u Istri, u nizu zabrana i restriktivnih mjera prema Hrvatima i Slovencima, našla se i ona o zabrani rada svih društava koja su sjedište imala u inozemstvu. Na udaru ove odredbe našla su se dva kulturno-prosvjetna i izdavačka društva: hrvatsko Društvo sv. Jeronima iz Zagreba i slovenska Mohorjeva družba iz Celovca. Oba društva su imala velike zasluge za širenje popularno-poučnih knjiga na "narodnom jeziku”. U novonastaloj situaciji gorički Slovenci su osnovali Gorišku Mohorjevu družbu, koja je svake godine izdavala knjige i kalendare te tako ublažavala odsutnost

19 Arhiv Istarskog književnog društva "Juraj Dobrila” u Pazinu (dalje: AH IKD), Osobni fond Bože Milanovića (dalje: OF BM), Milanović, Historijat Istarskog književnog društva (dalje: IKD) sv. Ćirila i Metoda (rukopis), b. o. (arhiv je u sređivanju).

20 Milanović, Istra u 20. stoljeću I, 145-146. 
celovečke Družbe. ${ }^{21}$ Potaknuti slovenskim primjerom, i Hrvati su pomišljali učiniti jednako. Međutim, Milanović kao spiritus movens svih hrvatskih akcija u Trstu i Istri priznaje da se nije usudio napraviti taj korak i to iz dva razloga. Smatrao je da bi sav teret oko rada zamišljene kulturno-izdavačke ustanove spao na njega, a on je ionako bio preopterećen kapelanskim poslovima i radom na uređivanju lista Istra. Velik problem je bio i kako pribaviti novčana sredstva za podizanje i funkcioniranje jedne takve ustanove. Iskreno priznaje: "Ja se nisam usudio odlučiti na takav korak." ${ }^{29}$

Inicijativu da i Istrani naprave nešto slično kao i Goričani dao je beramski župnik Josip Grašić, “najugledniji istarski župnik”. U Bermu pred Božić 1923. sastali su se kod Grašića Milanović, Ivan Pavić, župnik u Juršićima, ${ }^{23}$ Šime Frulić, grdoselski župnik, publicist Vladimir Sironić i beramski učitelj Marko Zlatić te odlučili da će u Trstu osnovati društvo čiji će cilj biti prosvjećivanje naroda u ćudorednom i kulturnom duhu. Na sastanku kod Berma također je odlučeno da iz Maribora u Trst dođe Vladimir Sironić kako bi pomogao osnivanju društva i ponovnom pokretanju PP-a.

Na početku 1924., u prvom broju PP-a, izišao je Grašićev proglas o osnivanju novog društva: "Duševne hrane svakako treba pružiti narodu - inače bi propao. Gdje se ne čita lijepa knjiga ondje zavlada nećudoređe, te započne sve propadati, narodno, gospodarski i vjerski (...) U tom pogledu treba da poduzmemo sve što se god dade učiniti. Niti malo ne smijemo odgađati (...) Tko ima dobru volju da pomogne oko toga da se to naše narodno poduzeće učvrsti i da se time položi čvrsti temelj za napredak našeg naroda neka se prijavi kao povjerenik. U to ime pomoz Bog!" ${ }^{24}$

Na prijedlog župnika Grašića, da bi se izbjegli vjerojatni problemi s državnom administracijom oko dobivanja dozvole, kao i zbog slabe financijske situacije, Društvo sv. Mohora za Istru u početku je djelovalo kao podružnica Goriške Mohorjeve družbe. Sam Milanović, iako je bio svjestan potrebe hrvatsko-slovenske suradnje i zdušno ju je podržavao, smatrao je da treba što prije ići na potpuno osamostaljenje Društva sv. Mohora za Istru. Bojao se da privremeno rješenje ne postane trajno, a to bi značilo da Odbor Goriške

21 Isto, 228

22 AH IKD, OF BM, Milanović, Historija IKD sv. Ćirila i Metoda (rukopis).

23 Milanovića su u šumi ispod Berma dočekali Grašić i Pavić. Doputovavši vlakom iz Trsta Milanović se nije iskrcao u Pazinu da ne bi pao u oči lokalnim fašistima s kojima je sve donedavno ratovao i koji su ga dobro poznavali. Iskrcao se na željezničkoj stanici u selu Heki i odande prečacima nastavio put do ugovorenog mjesta ispod Berma. AH IKD, OF BM, fasc: Ivan Pavić, Referat Ivana Pavića na glavnoj skupštini IKD sv. Ćirila i Metoda 19. XII. 1963. 
Mohorjeve družbe financira, a onda, što je logično, i određuje izdanja namijenjena Istri. Uz to, bio je sumnjičav prema goričkim svećenicima kad je u pitanju njihovo poznavanje istarske situacije i spremnost da se založe za narodno-preporodni rad u Istri. Tražiti od goričke Družbe da se posveti radu u Istri značilo bi, napokon, prihvatiti vlastitu nesposobnost. Zato je, prihvaćajući formalnu ovisnost kao privremeno rješenje, od početka inzistirao da Društvo sv. Mohora za Istru praktično samostalno nastupa. Stvar je utoliko bila lakša što gorički katolički intelektualci nisu imali nikakve želje da rad istarskog društva podvrgnu svome utjecaju. ${ }^{25}$

Na formalno osamostaljenje Društva sv. Mohora za Istru utjecala je tršćanska policija svojim traženjem da joj Milanović dostavi popis članova Društva. Svjestan da bi državna vlast mogla zabraniti rad Društva kad bi se ono prijavilo kao javna ustanova, Milanović je, potaknut primjerom Goričana, u pravila Družbe stavio kako se radi o bratovštini. Za bratovštinu kao crkvenu ustanovu nije trebalo tražiti dopuštenje vlasti, bilo je dovoljno odobrenje mjesnog biskupa. Dostavljena pravila tršćansko-koparski biskup Alojz Fogar odmah je odobrio. Tako je Društvo sv. Mohora za Istru, na talijanskom kao Sodalizio San Ermacora per l'Istria (Bratovština sv. Mohora za Istru), moglo i formalno započeti sa samostalnim radom. ${ }^{26}$

U Istri je već dugo vremena bilo prisutno Društvo sv. Jeronima iz Zagreba, književno-nakladnička ustanova. U predratnom vremenu sa svojih tristotinjak članova u Istri preko kojih je širilo poučno, vjersko i domoljubno štivo imalo je, za ondašnje prilike, dosta velik utjecaj kod istarskih Hrvata. Zato se kao izraz poštovanja prema svemu što je Društvo sv. Jeronima učinilo za Istru te kao izraz kontinuiteta razmišljalo da bi bilo zgodno uzeti naziv zagrebačkog društva kao što su to učinili Goričani uzimajući naziv celjske Mohorjeve družbe. No, ubrzo se odustalo od te zamisli jer je Društvo sv. Jeronima kod talijanskih vlasti bilo obilježeno kao jugoslavensko iredentističko. Prigodom jednog posjeta Zagrebu članovi Društva sv. Jeronima zamjerili su Milanoviću da Istrani za naziv svoga društva nisu uzeli naziv njihova društva. Taj su potez Istrana tumačili kao odvajanje i konkurenciju zagrebačkom Društvu. Kako se upravo tada održavala svetojeronimska godišnja skupština, Milanović je na skupštini objasnio razloge zbog kojih se u Istri krenulo s novim društvom. Tako je nesporazum odmah u početku riješen, pa je Društvo sv. Jeronima nastavilo ilegalnim kanalima,

25 AH IKD OF BM, Milanović, Historijat IKD.

26 Isto. 
najčešće preko Trsta, dostavljati svoja izdanja u Istru. ${ }^{27}$

Za svog 21-godišnjeg boravka u Trstu, uz ostale poslove, Milanović je upravljao i usmjeravao rad Društva sv. Mohora za Istru. Sve vrijeme obavljao je poslove predsjednika, tajnika i blagajnika. Za izdavanje i uređivanje knjiga brinuo se Vladimir Sironić. ${ }^{28}$ Do 1945 . Društvo je izdalo 58 naslova. Redovito izdanje za svaku godinu bila je Danica. ${ }^{29}$ Evo kako je izdavačku politiku opisao Milanović:

"Mi nismo nikad išli za tim da izdajemo originalna i umjetnička djela koja bi resila knjižnice, bogatila narodnu književnost i donosila nam priznanja i pohvale naobraženih ljudi. Sve je to za nas bio luksuz, koji si mi nismo htjeli priuštiti. To smo prepuštali slobodnom dijelu našeg naroda u Jugoslaviji. Nama koji smo živjeli pod tuđim jarmom, bilo je pred očima samo jedno: da budu naše knjige pomoć narodu u njegovoj borbi za opstanak. Zato nam je bilo milije pretiskati koju staru knjigu koju će naši seljaci veselo čitati, nego li izdati koje novo, originalno, pa makar i umjetničko djelo, za koje naš narod ne bi mario. Htjeli smo priučavati narod na čitanje, pružiti mu utjehu u nevoljama i progonima, odgajati ga u ćudoređu i čvrstoći karaktera i podučiti ga praktičnim potrebama života. Radi toga smo nastojali da budu svetomohorske knjige za naše pučanstvo privlačne, pučki pisane, odgojne i poučne”. ${ }^{30}$

Unatoč brojnim teškoćama, živeći u stalnoj materijalnoj oskudici, s malim brojem suradnika, pod stalnim pritiskom i budnim nadzorom cenzure, Društvo je, nema sumnje, bilo najznačajnija, jedno vrijeme i jedina, legalna hrvatska institucija u vrijeme fašističkog zatiranja svakog i najmanjeg iskaza hrvatskog identiteta u Istri. Gledano iz današnje perspektive, možemo slobodno reći da je obavilo svoju povijesnu misiju, naznačenu u Pravilima Društva: prosvjećivanje i odgajanje naroda u ćudorednom, narodnom duhu.

\section{Crkveno-vjerski okvir u zaštiti nacionalnih prava}

Ukidanjem višestranačja u Italiji te zabranom svih hrvatsko-slovenskih kulturno-prosvjetnih društava 1927., na društvenoj pozornici kao vidljivi izrazi "slavenske" nazočnosti u Julijskoj krajini ostali su samo PP i Društvo sv. Mohora za Istru, s nekolicinom djelatnika okupljenih oko ovih dviju ustanova. Međutim, sam Milanović priznaje kako je isto značenje kao njegov

27 Isto.

28 Božo Milanović, Hrvatski narodni preporod u Istri, 2. knjiga (1883-1947), Pazin 1973. (dalje: Hrvatski narodni preporod u Istri II), 527.

29 Isti, Istra u 20. stoljeću I, 231-234.

30 Isto, 234. 
rad i rad njegovih suradnika imao i "sitni” rad na terenu koji su podržavali istarski svećenici i ugledni seljaci-narodnjaci. Oni su svojim savjetom, primjerom i širenjem hrvatskih knjiga dali nemjerljiv doprinos borbi istarskih Hrvata protiv fašističkih negatorsko-asimilacijskih nastojanja prema istarskim Hrvatima. ${ }^{31}$

U takvoj situaciji najveća briga posvećivala se uređivanju PP “jer je on predstavljao i podržavao vezu, duhovno jedinstvo i javno mnijenje čitavog hrvatskog naroda u Italiji”. Kao čovjek s istančanim osjećajem za procjenu stvarnosti, Milanović je, zbog sve češćih zabrana i rigoroznije cenzure, predložio neke koncepcijsko-tehničke preinake lista. O nepravdama fašizma prema Hrvatima počelo se sve manje pisati; uvodni članak, do tada tiskan na prvoj stranici, prebačen je na drugu ili treću stranicu ili ga jednostavno nije bilo. Pretpostavljali su da uvodnici izazivaju najviše pozornosti kod vlasti, a, osim toga, seljaci ih najmanje čitaju. Umjesto uvodnika na prvoj stranici počele su se pojavljivati kratke informacije o zbivanjima u Istri i svijetu. Uz to redovito je objavljivan Politički pregled koji je bio neka vrst “dopisne političke škole”, dok su u Podlistku objavljivani poučni i domoljubni tekstovi. ${ }^{32}$

Od prvotne zamisli da se već 1926. stvori Seljački savez kao tijelo koje bi usmjeravalo i koordiniralo hrvatski politički rad u Istri brzo se, i to iz dva razloga, odustalo. $\mathrm{S}$ jedne strane nije bilo slobode koja bi omogućavala takav rad, a s druge strane nije bilo ni ljudi koji bi preuzeli obvezu vođenja jedne takve organizacije. Umjesto Seljačkog saveza pristupilo se stvaranju mreže povjerenika koji su u svojim sredinama preuzeli obveze širenja hrvatskih novina i knjiga te, u okvirima svojih mogućnosti, suzbijanje fašističke politike odnarođivanja. Ti povjerenici, njih 80-100 u cijeloj Istri, održavali su veze i dobivali upute i materijale iz centrale u Trstu. Radilo se konspirativno, tako da mnogi povjerenici nisu znali jedan za drugoga. ${ }^{33}$

Sve do 1931. hrvatsko-slovensko djelovanje, uza sve pritiske i represije, bilo je, formalno gledano, legalno. Te godine doneseni su zakoni o zabrani bilo kakve slavenske izdavačke ili političke djelatnosti. U praksi je to značilo ukidanje svih glasila i udruženja sa slavenskim predznakom. Tako je na javnom poprištu ostalo jedino Društvo sv. Mohora za Istru koje je smatrano crkvenom bratovštinom, pa kao takvo nije podlijegalo spomenutim zakonima.

31 Isto, 205.

32 Primjerice, objavljen je Šenoin roman "Čuvaj se senjske ruke”, roman Ivan Pregelja "Plovan pre Šime”, pripovijest iz istarskog života “Jelkin bosiljak” Eugena Kumičića i "Rosamunda”. Isto, 206.

$33 \mathrm{Na}$ ist. mj. 
U novim okolnostima, sve do konfinacije, Milanović je svoj rad i rad svojih suradnika usmjerio na pet područja: izdavanje knjiga, održavanje osobnih veza, pomoć đacima, borbu za crkvena prava kao dijela narodnih prava i političke kontakte. $^{34}$

Premda je tiskanje knjiga u svetomohorshoj nakladi bio zapravo jedini legalan oblik rada, i tu je trebalo biti oprezan. Karabinjeri i fašisti pratili su budno hrvatsku izdavačku djelatnost, pazeći da se ne bi pojavilo nešto, makar u književnim aluzijama, što bi imalo primjese kritike države i režima. Čak je i molitvenik Oče, budi volja tvoja tiskan 1936. potajno da ga tršćanska kvestura ne bi zaplijenila, pozivajući se na odluke vlasti u Gorici da i vjerske knjige moraju biti dvojezične, tj. da se uz svaku hrvatsku ili slovensku stranicu tiska i talijanski prijevod. K tome, svaka knjiga je morala imati odobrenje prefekture (nulla osta - “nema zapreke”). Dok su talijanske knjige to odobrenje dobivale odmah po traženju dozvole, hrvatske su, najčešće, morale čekati na "nulla osta” i po nekoliko mjeseci. Od 1938. vlasti u Gorici i Trstu nisu htjele izdati odobrenje za tiskanje bilo koje hrvatske knjige, čak i ako se radilo o prijevodu već odobrenih talijanskih knjiga. ${ }^{35} \mathrm{Na}$ taj način je, poslije zabrane tiskanja novina, to učinjeno i s knjigama.

Kao jedino hrvatsko štivo, pučki kalendar Danica trebao je preuzeti ulogu zabranjenih novina i knjiga. Nacionalno značenje i dalje su zadržali molitvenici. Oni su se još uvijek slobodno mogli čitati. Za seljački svijet koji je iz njih navečer molio važno je bilo da se Bogu može obratiti na svom jeziku. Molitva na narodnom jeziku osim svoje vertikale, odnosa prema Bogu, imala je i horizontalno, nacionalno značenje. Na individualnoj psihološkoj razini sigurno je važna bila spoznaja da i sam Bog "razumije” naš jezik. Ako se na tom jeziku može razgovarati s Bogom onda taj jezik, kao i narod koji se njime služi, ima svoje dostojanstvo i povijesno mjesto.

Prestanak izlaženja PP za politički rad bio je nenadoknadiv gubitak. Iluzorno je bilo očekivati da, makar i pojačana, izdavačka djelatnost Društva sv. Mohora može nadomjestiti novine. Zato se u ovom vremenu intenziviraju sastanci i osobni kontakti. Mnoge od tih sastanaka i osobnih susreta organizirao je Milanović kod sebe u župi sv. Ivana, a od 1938. u župi sv. Antuna Novog, kamo ga je te godine premjestio biskup Santin. Na sastanke održavane u strogoj tajnosti dolazili su svećenici, bogoslovi, đaci, studenti i seljacipovjerenici. Od tih ljudi stvaralo se novo intelektualno i političko vodstvo 
istarskih Hrvata, koje će postupno zamijeniti ono predratno. Na sastancima se razgovaralo o društveno-političkoj situaciji u Istri i mogućnostima rada u narodu, s narodom i za narod. Mnogi su u Trst došli depresivni i bez ikakve vjere u mogućnost bilo kakvog djelovanja, a vratili su se s vjerom u potrebu sitnog, često nezamjetnog, rada u svojim sredinama. ${ }^{36}$

Istaknuto mjesto u tršćanskom razdoblju Milanovićeva djelovanja imala je briga za đake, a posebno za sjemeništarce u koparskom sjemeništu. Pri tome se nije radilo o nikakvoj "klerikalnoj uskogrudnosti” zaokupljenoj staleškim interesima. Hrvatski su, naime, sjemeništarci u Kopru pohađali talijansku gimnaziju i bili izloženi sustavnoj talijanizaciji u samom sjemeništu. Plan je bio jasan, ako se uspije talijanizirati te hrvatske sjemeništarce, kasnije bogoslove i buduće svećenike, jedine intelektualce po istarskim hrvatskim selima, bit će uklonjena i posljednja ozbiljna brana protiv talijanizacije. Za Milanovića je očuvanje nacionalne svijesti kod hrvatskog svećeničkog podmlatka bilo “životno pitanje našeg naroda”. Rad na tom planu u početku je išao preko roditelja sjemeništaraca. Kasnije je zbog političkog rada nekoliko sjemeništaraca iz VI. razreda biskupijske gimnazije sv. Vida kraj Ljubljane premješteno u koparsko sjemenište. Zadojeni jugoslavenskim duhom oni su svoju nacionalno-političku orijentaciju prenosili i na hrvatske đake. ${ }^{37}$

Milanović je za ljetnih praznika 1927. s dvadesetak hrvatskih i slovenskih sjemeništaraca iz koparskog sjemeništa bio na trodnevnom izletu u Višarju na austrijsko-talijanskoj granici. U javnosti je izlet predstavljen kao hodočašće pa je njegov religiozan karakter budio manje sumnje kod državnih i sjemenišnih vlasti. Tu su u brdovitoj tišini raspravljali i razgovarali o hrvatskoj prošlosti i književnosti, o situaciji u Istri. Izlet je imao veliko značenje za buduće “držanje zajedno” u koparskom sjemeništu i kasnije u goričkoj bogosloviji. Mnogi su putujući iz Istre u Kopar ili Goricu ili na povratku svraćali kod Milanovića gdje ih je on srdačno primao, razgovarao s njima i na jedan dojmljiv način prenosio im potrebu da i oni, danas-sutra, kad postanu župnici, ne zanemare rad na očuvanju nacionalnog identiteta istarskog hrvatskog, pretežno ruralnog, svijeta. ${ }^{38}$ Isto tako nastojao je da hrvatski sjemeništarci i bogoslovi ljetne praznike provedu kod nacionalno svjesnih svećenika. Tu su izbliza mogli vidjeti duhovnu vertikalu svećeničkog rada, ali i ništa manje važnu horizontalu tog rada u kojoj je borba za nacionalna prava bila sastavni dio njihova poslanja.

36 Isto, 209.

37 Isto, 210.

$38 \mathrm{Na}$ ist. mj. 
Za nastojanje da hrvatski sjemeništarci "ne postanu Talijani u hrvatskoj koži” korištene su i druge prigode kao što su mlade mise, razne crkvene svečanosti, pjevanje, izleti. Milanović je s mnogima osobno razgovarao i poticao ih da $u$ sjemeništu međusobno razgovaraju hrvatski, iako je znao da zbog toga mogu imati poteškoća. Kako hrvatski roditelji najčešće nisu mogli snositi troškove boravka svoje djece u sjemeništu i troškove školovanja, hrvatski svećenici su na razne načine podupirali hrvatske sjemeništarce. Osjećali su se odgovornim pred Bogom i narodom za odgoj svojih nasljednika. ${ }^{39}$

Hrvatski svećenici i organizirani dio hrvatsko-slovenske nacionalne zajednice, koji se nazivao “Organizacija”, na čelu s Jankom Kraljem kao predsjednikom i Milanovićem kao tajnikom, pomagali su materijalno i svjetovne đake. Oblici rada s njima bili su isti kao i sa sjemeništarcima: osobni sastanci, predavanja, knjige, đački listovi. U svemu je značajno bilo održavanje veza s Jugoslavijom, odakle su naručivane knjige, časopisi i novine. Velik broj knjiga slala je Jugoslavenska Matica i njezin agilni tajnik Istranin Franjo Baf. U prebacivanju knjiga iz Jugoslavije i njihovu raspačavanju angažirani su bili i službenici jugoslavenskog konzulata. Kao diplomati slobodnije su se kretali te nisu bili izloženi pretresima na granici. Tako su i na taj način, kao predstavnici “jugoslavenske” (hrvatske i slovenske) manjine u Trstu, štitili njezine interese. $^{40}$

Na početku 1938. u podužem pismu upućenom hrvatskim bogoslovima u Gorici (25 tipkanih stranica) Milanović iznosi svoju koncepciju uloge svećenika kao narodnog radnika, potrebu odgoja za tu ulogu, kao i neke praktične upute da bi bogoslovi, kao budući svećenici, mogli adekvatno ispuniti tu ulogu. Odmah na početku pisma upozorava ih: "Vi imate postati ne samo svećenici nego i narodni radnici i vođe. Radi toga treba da se spremate za tu važnu zadaću”. ${ }^{41}$ Stavljajući naglasak na nacionalno-političku ulogu i formaciju bogoslova, nije smatrao nevažnom onu duhovnu, užesvećeničku formaciju. No, kako je zbog jasnog nastojanja talijanske fašističke politike da i crkvu talijanizira, u opasnosti bila upravo njihova nacionalna pripadnost i svijest o potrebi i nacionalnog rada, Milanović se, tada kao neprijeporni autoritet među istarskim hrvatskim svećenicima, osjetio pozvanim da svoje buduće kolege upozori kako u ime vječnih ideala ne bi smjeli zanemariti ni one zemaljske, a u koje je, po njemu, spadala borba za opstanak hrvatskog naroda u Istri, dotično

\footnotetext{
39 Isto, $210-211$.

40 Isto, 215.

41 AH IKD, OF BM, Pismo bogoslovima 1. II. 1938., 1.
} 
“da ostane svoj na svome, da zadrži svoj jezik i svoje običaje te da svoju dotadašnju kulturu ne izgubi nego da si je sačuva i dalje izgrađuje, ukratko da kao narod ne propadne nego i dalje da živi”. ${ }^{42}$

Kratkim povijesnim osvrtom na ono što su istarski Hrvati ostvarili na nacionalnom planu od druge polovice 19. st. do trenutka u kojem se obraća bogoslovima, Milanović, s jedne strane želi ukazati na veliku ulogu svećenika u tim ostvarenjima, a s druge strane upozoriti bogoslove da su pozvani nastaviti tamo gdje su stali njihovi predšasnici. U protivnom, u pitanju je sam opstanak istarskih Hrvata. Najodgovorniji na tom polju su intelektualci kao glave i predvodnici naroda. Kako su nakon fašističkih progona svećenici ostali jedini hrvatski intelektualci u Istri njihova je odgovornost kao narodnih vođa i radnika tim veća. ${ }^{43}$

Teorijsko uporište za svoja promišljanja nalazi u Bibliji iz koje se može iščitati da je Božja volja bila da se na zemlji pojave različiti narodi. Kao "od Boga stvoreni organizam, imade svaki narod svoja naravna prava”. Govor o "naravnom pravu naroda” potkrepljuje navođenjem dijelova iz Mahnićeve knjige Več luči, u kojoj ovaj “duboki mislilac i filozof” ističe da imamo "neizbrisivo pravo” čuvati svoju narodnost i jezik kao dar Božji. Zato svi oni koji uskraćuju narodu njegovo prirodno pravo na identitet griješe protiv volje Stvoriteljeve i načela pravde. ${ }^{44}$

I druga Milanovićeva teoretska promišljanja o odnosu vjere i nacije, o štetnom utjecaju liberalizma na društveni život naroda, o problemu talijanske politike odnarođivanja na tragu su Mahnićevih predratnih shvaćanja. Za narod može ozbiljno i ustrajno, bez traženja nadoknade raditi samo onaj koji ima uporište u kršćanskom shvaćanju povijesti, života i sudbine čovjeka. Liberalna inteligencija bez uporišta u vječnim istinama sklonija je lutanju i u politici, sve do zanemarivanja stvarnih narodnih interesa. Prema talijanskoj Katoličkoj akciji bio je skeptičan. Računao je da, makar i nesvjesno, može postati sredstvo talijanizacije. Zato je, ne sumnjajući u ispravnost njezina vjerskog programa, bio spreman započeti s Katoličkom akcijom i kod istarskih Hrvata, ali pod uvjetom da se Hrvatima osigura jezična sloboda i neovisnost od biskupskog vodstva talijanske Katoličke akcije. ${ }^{45}$

U želji da kod bogoslova razvije oduševljenje za ideju jugoslavenstva

\footnotetext{
42 Isto, 5.

43 Isto, 4 .

44 Isto, 7-8.

45 Isto, 10-17.
} 
slijedio je priklanjanje Hrvatskog katoličkog pokreta u Istri ideji integralnog jugoslavenstva. Iznoseći tada aktualne dileme jesu li Srbi, Hrvati i Slovenci tri plemena jednog naroda te hoće li povijesni proces ići u pravcu stvaranja jednog jugoslavenskog naroda, piše bogoslovima: "U tom pogledu smo mi Hrvati i Istrani pristaše što višeg jedinstva i ujedinjavanja u jedan narod (...). U svakom slučaju mi ostajemo Hrvati, dio hrvatskog naroda i Jugoslaveni (dio jugoslavenskog naroda), koji je materijalno jedan, a formalno (po svojoj svijesti) tri naroda (..)”. ${ }^{46}$

Za svećenike, koji su stjecajem povijesnih (ne)prilika postali kreatori i nositelji hrvatske politike u Istri, cilj te politike bila je briga za očuvanje biološkog opstanka hrvatskog naroda u Istri i stvaranje pretpostavki za njegov napredak na svim područjima društvenog života. Za Milanovića je narod organizam, sastavljen, kao i svi organizmi, od raznih dijelova. Da bi organizam funkcionirao svi njegovi dijelovi, a posebno glava koju čini politička elita, u konkretnom istarskom slučaju svećenici, mora raditi za napredak tog organizma. Najbolja sredstva za ostvarenje političkog cilja su buđenje nacionalne svijesti, širenje pisane riječi, gospodarsko teoretsko prosvjećivanje i praktično uzdizanje, jednom riječju sitni rad o kojem je pisao Stjepan Radić. Spominjanje Radićeva sitnog rada pokazuje Milanovićevo poznavanje političke koncepcije ovog hrvatskog političara. Kvalitetan, tj. uspješan, politički rad, po Milanoviću, nije moguć bez jake organizacije. Zajednički nastupi Hrvata i Slovenaca ne isključuju potrebu posebne, međusobno neovisne hrvatske i slovenske političke organizacije. Radi zajedničkog dobra i efikasnijeg nastupa prema van, njihov bi rad trebao koordinirati zajednički odbor. ${ }^{47}$

Na kraju ovog pisma koje sadrži sve elemente programatskog spisa nacionalnog rada, autor donosi nekoliko konkretnih zadataka. Pretpostavka za ostvarenje svih drugih zadataka je da se kao bogoslovi, unatoč poteškoćama i mogućim krizama, opredijele za svećenički poziv. U svemu neka računaju na Božju pomoć i na potrebu žrtve po uzoru na Isusa Krista, velikog svećenika. Uz učenje teološko-filozofskih disciplina, "treba da se usavršavaju u poznavanju svog književnog materinskog jezika” (podcrtano u originalu, op. aut.). Ovaj zadatak će najbolje ispuniti ako budu čitali hrvatske knjige, bilježili hrvatske izraze, gledali u hrvatski pravopis i vježbali pisanje hrvatskih sastava. Osim ovih općih znanja bilo bi dobro da se usavršavaju, ovisno o osobnim sklonostima, i u posebnim znanjima i vještinama: neki u poznavanju

46 Isto, 19-20.

47 Isto, 20-22. 
hrvatske književnosti, drugi u poznavanju hrvatske povijesti, treći u izučavanju zemljopisnih osobina Istre, neki u izučavanju glagoljice, neki u glazbi, drugi u poznavanju prirodnih znanosti, neki opet u poznavanju poljodjelstva na teoretskoj i praktičnoj razini. Ovo posljednje smatra posebno važnim jer ako se svećenik zanima za poljodjelstvo bliži je seljacima i ima više utjecaja na njih. ${ }^{48}$

U Dodatku iznosi praktične prijedloge za vježbanje u hrvatskom jeziku. Što češće napisati neki sastav koji će netko ispraviti - na taj će način najbolje uočiti gramatičke i pravopisne pogreške. Za Uskrs mogu napisati sastav, temu mogu sami izabrati, te sastav dostaviti Milanoviću. Svaki sastav bit će ispravljen i vraćen autoru, a ako se pokaže dobrim, mogao bi biti uvršten u Danicu. Svim bogoslovima preporučuje časopis Hrvatski jezik koji je u Zagrebu počeo izlaziti početkom 1938. godine. Dostavlja im na uvid prvi broj i poziva ih da se pretplate na časopis preko Društva sv. Mohora za Istru. ${ }^{49}$

Borba za očuvanje narodnog jezika u liturgiji krajem 19. st. prelazi uske crkvene okvire i prerasta u nacionalno-političko pitanje par excellance. U mjeri u kojoj su Hrvati upotrebu staroslavenskog i narodnog jezika doživljavali kao pitanje očuvanja jedne od značajnih hrvatskih povijesnih vertikala, u istoj mjeri su Talijani, dotično njihova liberalna politička elita, smatrali da potiskivanje i eliminacija glagoljice iz liturgije otvara put lakšoj talijanizaciji, a argumenti o povijesnom pravu Talijana na Istru dobivaju na težini. Zato borba za očuvanje "stečenih prava” na narodni jezik u liturgiji poprima pod Italijom sve dramatičnije oblike što su talijanski pritisci bili izravniji i bezobzirniji. ${ }^{50}$

U jednom članku u PP-u Milanović pitanje sve češćih slučajeva demonizacije i zabrane staroslavenskog i hrvatskog jezika liturgije u Istri u doba fašizma stavlja u okvir sve prisutnijeg poganskog nacionalizma. Za razliku od kršćanskog nacionalizma koji ne čini drugome zla, poganski nacionalizam "hoće da u svoju korist druge tlači, izrabljuje i uništava”. Nažalost, nastavlja Milanović, događa se da poganski nacionalizam prelazi i crkvene pragove s jasnom namjerom upotrebe Crkve za trenutne političke ciljeve. U Istri, gdje fašizam ne preza od miješanja u crkvene poslove, neki crkveni djelatnici, da se ne bi zamjerili politici, prihvaćaju njezin diktat na čisto crkvenom planu upotrebe jezika u liturgiji. Misao o tome kako je Crkva svoju spasenjsku poruku

48 Isto, 22-24.

49 Isto, 25.

50 Stipan Trogrlić, “Porečko-pulska biskupija u vrijeme biskupa Ivana Flappa (1885.-1912.)", Problemi sjevernog Jadrana, 8, 2003., 97-102. 
uvijek u povijesti posredovala na narodu razumljivom jeziku nema svoje utemeljenje u povijesnim činjenicama, ali se može razumjeti kao promidžbena obrana Crkve. ${ }^{51}$

Kako se ne bi poistovjetilo djelovanje pojedinaca s djelovanjem Crkve u cjelini, što bi moglo izazvati animozitet kod hrvatskog puka prema Crkvi kao takvoj, autor kao obrazovani teolog upozorava na potrebu razlikovanja Božjeg i ljudskog djelovanja u Crkvi. Za razliku od božanskog elementa koji je nepogrešiv, ljudski je podložan grijehu i može se prikloniti nezdravom nacionalizmu. Zato je prva dužnost vjernika razlikovanje božanskog i ljudskog djelovanja u Crkvi. Odmah iza te dužnosti je ona o upoznavanju crkvene hijerarhije s pritiscima i nasiljem nad upotrebom narodnog jezika u crkvenim obredima. No, najvažniji lijek protiv odnarođivanja hrvatskog dijela Crkve je duh "značajnosti i ustrajnosti” kod njezinih članova, u prvom redu kod svećenika kao vjerskih i narodnih vođa. Narod će lakše te značajke poprimiti ako ih vidi kod svećenika, a da bi ih svećenici imali, moraju biti odgajani u tom smislu. ${ }^{52}$

Zanimljivo je Milanovićevo shvaćanje kako očuvanje hrvatskog jezika u crkvi ima čak više značenje nego njegovo očuvanje u školama. Jezik kao bitan dio nacionalnog identiteta, u crkvi, kroz obrede i pjesme vezane uz neke egzistencijalne ljudske situacije, djeluje duboko emocionalno, za razliku od njegove školske funkcije koja ostaje na logičko-racionalnoj razini. Na praktičnoj razini župnicima se preporučuje da biskupima dostavljaju pismene peticije ili da ih barem usmeno upoznaju s nepravdama koje doživljavaju glede jezičnoliturgijske prakse. ${ }^{53}$

\section{Neslaganja s nastupnim potezima biskupa Santina}

Neko je vrijeme Tršćansko-koparskom biskupijom upravljao gorički nadbiskup Carlo Margotti, koji je, prema Milanovićevoj ocjeni, "bio popustljiv i prema nama i prema fašistima”. ${ }^{54}$

Sredinom 1938. Sveta Stolica je na katedru sv. Justa u Trstu imenovala Antonija Santina, dotadašnjeg riječkog biskupa, rođenog u Rovinju, školovanog u koparskom sjemeništu i goričkoj bogosloviji. U ranom razdoblju svoje biskupske službe u Trstu, sigurno pod utjecajem nacionalnog djelovanja

\footnotetext{
51 “Za naš jezik u Crkvi”, PP, god. XXV, br. 32 (Trst, 22. V. 1924.), 1.

$52 \mathrm{Na}$ ist. mj.

53 Milanović, Istra u 20. stoljeću I, 213.

54 Isti, Moje uspomene, 100.
} 
hrvatskih i slovenskih sjemeništaraca i bogoslova s kojim se susretao punih 12 godina, a koje je (djelovanje) i u crkvenim krugovima označavano kao “politikantstvo”, Santin je prema hrvatsko-slovenskim jezičnim zahtjevima zauzeo dosta negativniji stav od svog prethodnika.

Imenovanje Zvonimira Brumnića, tadašnjeg profesora hrvatskog jezika u koparskom sjemeništu, upraviteljem župe u Zrenju i postavljanje svećenika porečko-pulske biskupije Zvonimira Zamlicha (Zamlića) na njegovo mjesto, Milanović je bolno doživio. O tom događaju piše: "Ta me promjena pogodila u srce. Smatrao sam je političkim činom, uperenim protiv nas Hrvata. Iz sjemeništa je bio izbačen jedini ondašnji (hrvatski, op. aut.) svećenik a na njegovo mjesto bio imenovan drugi, koji se pokazivao protivan nama i našim narodnim idealima te se pridružio Talijanima (Sirottijevoj skupini). Dok je od svih cijenjeni Brumnić ostao u Kopru i kao svećenik bio obični nadglednik đaka, Zamlich je odmah imenovan sjemenišnim podravnateljem. Za podučavanje hrvatskog jezika u srednjoj školi nije bio nipošto spreman, ali se o tome nije vodilo računa (...)."55

U Spomenici biskupu Santinu zbog Brumnićeva premještaja, restriktivnih mjera prema hrvatskim i slovenskim gojencima u koparskom sjemeništu te hrvatskim i slovenskim svećenicima, Milanović, kao njezin autor, spominje da su hrvatski i slovenski svećenici dali “oduška uvrijeđenosti koju smo osjetili”. ${ }^{56} \mathrm{Na}$ početku Spomenice potpisnici drže svojom dužnošću obavijestiti Santina “(...) da se poslije tako kratkog vremena Vaše uprave osjećamo neizrecivo razočaranima. Glavni uzrok jesu Vaši dekreti kojima ste započeli s jedne strane odstranjivati iz crkve naš jezik, a time neizravno i naš narod, dok ste s druge strane iz koparskog sjemeništa otpremili jedinog našeg slavenskog svećenika". ${ }^{57}$

Dekreti o rigidnom ograničavanju uporabe hrvatskog i slovenskog jezika u župama s hrvatskom, odnosno slovenskom većinom, u pjevanju, propovijedanju, čitanju i u drugim liturgijskim obredima "kod Slavena” izazivaju nemir i nezadovoljstvo. Najčudniji i najmanje opravdan je dekret o zabrani poučavanja vjeronauka na materinskom jeziku. Nešto takvo nije poduzeo nijedan biskup Julijske krajine, pa čak su se i fašističke vlasti sustezale od takvih

55 Isti, Istra u 20. stoljeću I, 245.

56 Na ist. mj.

57 Pismo slavenskog svećenstva biskupu Santinu od 30. studenog 1938. Prema: Lavo Čermelj, Il vescovo Antonio Santin e gli Sloveni e Croati delle diocesi di Fiume e Trieste e Capodistria, Inštitut za narodnostna vprašanja pri Univerzi v Ljubljani, Ljubljana 1953., 86. 
mjera. ${ }^{58}$ Zato su, upozorava Spomenica, ti dekreti "nasilje nad prirodnim i pozitivnim pravom vjernika” da se pastoralni rad obavlja na materinskom jeziku. Zabrana, pak, poučavanja vjeronauka na materinskom jeziku ne može se opravdati drugim načelima doli onim protukršćanskim, kojima je potom moguće nijekati temeljna osobna prava, ili onim “državolatrije” za koju su djeca više vlasništvo države, nego Božje ili roditelja. ${ }^{59}$

Prema Spomenici, ne manje iznenađenje kod "slavenskog” klera izazvao je dekret o imenovanju Zvonimira Brumnića, prefekta i profesora hrvatskog jezika, tada jedinog "slavenskog svećenika” u koparskom sjemeništu, za župnog pomoćnika u Zrenju (Buzetski dekanat). Ovaj se biskupov potez ne može opravdati pastoralnim razlozima jer se umjesto dotadašnjeg župnog pomoćnika Ernesta Beléa, premještenog u Sovinjak, moglo imenovati nekog drugog svećenika, tim više što je u župnoj kući u Sovinjaku već boravio jedan svećenik kojemu je biskup ubrzo našao novu destinaciju, a sve da bi oslobodio prostor za Brumnića. Zbog toga je premještaj svećenika Brumnića kod hrvatskih i slovenskih svećenika doživljen kao politički čin. ${ }^{60}$

Na kraju Spomenice nabrajaju se i druge nepravde prema hrvatskom i slovenskom svećenstvu i jeziku, ne samo u Tršćansko-koparskoj biskupiji, nego i u drugim dijecezama Julijske krajine. Talijanski svećenici, iako su u koparskom sjemeništu učili hrvatski jezik osam godina, obično ne nauče dobro ni čitati hrvatski. Zahtjev da se tjedni broj sati hrvatskog sa 1,5 sata poveća na 3 sata ostao je bez rezultata. Neprirodnim im se činilo da u upravi koparskog sjemeništa i profesorskom zboru nema ni jednog hrvatskog svećenika. Iako su o tom problemu pisali Santinu prilikom imenovanja za tršćansko-koparskog biskupa, on se nije puno obazirao na to, čak je iz sjemeništa uklonio jedinog hrvatskog svećenika. Zato slavenski svećenici očekuju od biskupa ispravak dekreta što se tiče jezika crkvenog pjevanja i poučavanja vjeronauka te očekuju da vrati Brumnića u koparsko sjemenište kao stalnog pro-

58 Radilo se o dekretima od 1. i 27. X. 1938. upućenim Alojziju Kocijančiću, upravitelju župa Koštabona i Pomjan (dekanat Krkavče, Koparska biskupija), kojima biskup Santin određuje da se u ove dvije župe, s izrazitom slovenskom većinom, uvedu dvojezične propovijedi, na talijanskom i slovenskom. Na opću konsternaciju vjernika naišla je odredba o držanju vjeronauka na talijanskom u Pomjanu. Još gore je prošao Ernest Belé, župnik u Zrenju. Njemu je Santin naredio, nakon 80 pritužbi talijanske manjine (u župi je bilo 1720 Hrvata i 321 Talijan), da propovijedi na hrvatskom može držati na jutarnjim misama svake druge nedjelje, dok je na glavnoj župnoj misi morao propovijedati na talijanskom jeziku. Vjeronauk je i hrvatskoj djeci bio obvezan držati na talijanskom jeziku. Kad je župnik glasno izrazio svoje rezerve protiv takvog postupanja prema većini vjernika, Santin mu je odgovorio: "Mi smo u Italiji pa je pravedno da prednost imaju Talijani”. Čermelj, isto, 83-85.

$59 \mathrm{Na}$ ist. mj.

60 Isto, $87-88$. 
fesora hrvatskog jezika s 3 sata hrvatskog jezika u svakom razredu. ${ }^{61}$ Iako je Spomenicu potpisalo 56 hrvatskih i slovenskih svećenika, ona, kao ni osobno posredovanje Milanovića i svećenika Tome Banka kod biskupa Santina, nije dala rezultata. Moglo bi se reći da je čak imala kontraučinak. Biskup Santin je Leopoldu Jurci, župniku u Trvižu, misleći da je on skupljao potpise za Spomenicu, napisao prekoravajuće pismo uz napomenu da ga "nikakva spomenica neće zadržati niti za korak" ${ }^{62}$

Razočarano ovakvim biskupovim odgovorom, slavensko svećenstvo Udinske, Goričke, Tršćansko-koparske, Porečko-pulske, Riječke i Zadarske biskupije obratilo se novom Spomenicom papi Piju XI. s molbom za osnivanje sjemeništa s hrvatskim i slovenskim jezikom kao službenim jezikom. Autor i ove Spomenice je bio Milanović, što je samo još jedan dokaz i povjerenja i autoriteta koje je među svojim kolegama uživao. Izražavajući svoju sinovsku odanost papi i Crkvi, Spomenica spominje ranije spomenice slavenskog klera Tajništvu Svete Stolice i raznim kongregacijama u kojima su te institucije nastojali upoznati sa svojim poteškoćama u pastoralnom radu. U svim tim spomenicama središnje mjesto zauzimao je zahtjev za osnivanjem sjemeništa na hrvatskom jeziku i poštivanje načela pravde i prava općenito u crkvenim poslovima. U postojećoj situaciji najbolje bi rješenje, prema Spomenici, bilo podići za hrvatske i slovenske dječake u Italiji sjemenište u kojem bi njihov materinski jezik bio jezik poučavanja. A ako se ipak takvo sjemenište ne može osnovati onda se ponizno moli da papa svojim autoritetom ukloni nepravde prema učenju materinskog jezika u sjemeništu i prema isključivanju slavenskog svećenstva iz uprave sjemeništa i profesorskog zbora. U potvrdu opravdanosti iznesenog zahtjeva Spomenica se poziva na nedavno izišli dokument Kongregacije za sjemeništa. ${ }^{63}$ Dakako, pri tome se ne želi od pape sakrivati ni one žalosne, i ne tako rijetke, slučajeve zabrana, sve do ukidanja materinskog jezika u liturgiji zbog čega slabi vjera i kršćanski život u slavenskim župama. S pouzdanjem se očekuje da papa svojim autoritetom pridonese da se u "našim krajevima uspostavi pravda i mir kako bi oživjela vjera i ljubav", ${ }^{64}$

Još dok je Santin bio biskup u Rijeci, Milanović mu je poslao pismo u kojem mu dokazuje kako je hrvatski obrednik odobrila Sveta Stolica pa ga legitimno mogu upotrebljavati vjernici Hrvati i u njegovoj biskupiji. Santin

\footnotetext{
61 Isto, 89.

62 AH IKD, OF BM, Leopold Jurca, Bilješke, b.o.

63 AH IKD, OF BM, dok. broj: M2A029, Spomenica na latinskom od 25. IV. 1939.

64 Na ist. mj.
} 
mu je odgovorio da ne može prihvatiti njegovo objašnjenje i sugestiju. Takav se odgovor mogao očekivati jer je Santin od samog dolaska na čelo Riječke biskupije oštro nastupio protiv uporabe slavenskog jezika u obredima. U Kastavskom dekanatu, kolijevci staroslavenske liturgije, zabranio je ne samo pjevanje hrvatskih pjesama tijekom mise, nego je odlučio zabraniti hrvatsko pjevanje Tebe Boga hvalimo i upotrebu hrvatskog jezika pri dijeljenju sakramenata, vođenju procesija, prilikom blagoslova i pogrebnih obreda. Od Kongregacije za obrede uspio je dobiti dozvolu za svoje nakane, a objašnjenje za traženje dozvole bilo je kako Talijani njegove biskupije kao granične biskupije teško podnose upotrebu "slavenskog jezika" ${ }^{65}$

Suočen i u Tršćansko-koparskoj biskupiji s istim jezično-liturgijskim problemima kao i u Riječkoj biskupiji, Santin je za vrijeme vizitacije u župi sv. Antuna na početku lipnja 1939. zamolio Milanovića da upotrijebi svoj autoritet za pomirljivije odnose i približavanje slavenskog i talijanskog klera. Spomenuo mu je kako je talijanski kler, osim nekih izuzetaka, otvoren prema svima te da osim jezika nema nikakve razlike između "Slavena” i Talijana. Kad mu je Milanović odgovorio da su "naši zahtjevi uistinu mali”, Santin je primijetio kako se primarno ne radi o zahtjevima, nego o duhu zajedništva. U slavenskim župama, smatrao je Santin, može se propovijedati i pjevati na slavenskom, dok to isto tražiti za neke druge, značilo bi ići glavom kroza zid. Na Milanovićevu objekciju da ni slavenski kler nije protivan duhu zajedništva, samo je primijetio: "Eh ne, nije tako, toliki su... Dobro činimo što možemo" ${ }^{66}$

Milanović je iskoristio susret da bi Santina podsjetio kako bi trebao u koparsko sjemenište umjesto maknutog Brumnića postaviti nekog "slavenskog" svećenika. Iznio je i primjedbu na postavljanje talijanskih svećenika, koji slabo ili nikako ne znaju hrvatski, u hrvatske župe. Santin mu je napomenuo da je u svojoj protalijanskoj sjemenišnoj kadrovskoj politici uvjetovan i pomoću od 10 do 20 tisuća lira koju sjemenište dobiva od talijanske vlade, a što se tiče druge primjedbe nije vidio u čemu je problem. On šalje talijanske svećenike u hrvatske župe da bi naučili hrvatski, a u početku, dok ne nauče, dovoljno je da znaju pročitati nešto na hrvatskom jeziku. ${ }^{67}$ Ovaj susret jasno je pokazao dva pristupa "slavenskom pitanju”. Jedan je karakterističan za ne malen dio hijerarhije talijanske nacionalnosti - za nju nije bila upitna potreba discipliniranja slavenskog svećenstva, dok je slavensko svećenstvo to discipli-

65 Milanović, Hrvatski narodni preporod u Istri II, 547.

66 AH IKD, OF BM, Milanovićeva bilješka (bez datuma).

67 Milanović, Moje uspomene, 101. 
niranje smatralo ugrožavanjem prirodnih nacionalnih prava svojih sunarodnjaka te doživljavalo kao stavljanje hijerarhije u službu politike talijanizacije Hrvata i Slovenaca.

Iz samih crkvenih krugova širile su se informacije kojima je cilj bio kompromitirati Milanovića u očima biskupa Santina. Već spominjani Zvonimir Zamlich (Zamlić) prenio je Santinu, a ovaj je to pričao dr. F-u (vjerojatno se radi o bivšem tršćansko-koparskom biskupu Alojziju Fogaru, op. aut.) kako ga je na izražavanje “'slavenskog’ nezadovoljstva” u sjemeništu poticao svećenik Milanović. Zamlich, već od ranije poznat kao pristaša Sirottijeve radikalno protalijanske struje u sjemeništu, po vlastitom priznanju, odbio je prijedlog starijeg kolege Milanovića i javno se distancirao od njega. Takvo Zamlichevo ponašanje, prema informacijama porečko-pulskog biskupa Trifuna Pederzollija, prenesenim biskupu Santinu, uskoro je došlo na naplatu. Kad je Zamlić 1939. kao postdiplomant u Rimu dobio stipendiju hrvatskog zavoda sv. Jeronima, iz određenih krugova nastojalo mu se oduzeti pravo na stipendiju. Iako Pederzolli ne spominje tho je iza toga stajao, jasna je aluzija da je to djelo “sveprisutnog Milanovića”. Santin je, također, raspolagao informacijama kako slavenski svećenici šalju spomenice u Beograd, odakle ih jugoslavenska vlada dostavlja u Vatikan. Na taj način te spomenice izmiču kontroli fašističke vlasti i dobivaju međunarodno značenje. ${ }^{68}$

\section{Evolucija odnosa prema NOP-u}

Sredinom travnja 1941. Milanovića je posjetio narednik oružnika (karabinjera) i pozvao ga da pođe s njim do policijske uprave (kvesture) gdje mu je priopćena odluka o konfinaciji u grad Orvieto, stotinjak kilometara sjeverozapadno od Rima. Odluka o konfinaciji temeljila se na prijavi špijunske fašističke organizacije koja je kvesturi predočila dokaze o Milanovićevu "slavenskom iredentističkom radu”. Na intervenciju biskupa Santina ipak mu je, kao manje zlo, za mjesto konfinacije određen grad Bergamo nedaleko od Milana. U Bergamu su, naime, već bila konfinirana dvojica slovenskih svećenika, Ivan Bidovec i Ivan Mezinec, pa je biskup vjerojatno računao da će mu u konfinaciji biti lakše u društvu subraće svećenika, političkih istomišljenika. Osim toga, veća udaljenost od Rima uvjetovala je i slabiji nadzor i, koliko-toliko, šire mogućnosti djelovanja. U Bergamu je bio smješten u biskupskoj zgradi Casa del clero (Svećenički dom) u kojoj su do pojave konfiniraca boravili stari i

$68 \mathrm{Na}$ ist $\mathrm{mj}$. 
bolesni svećenici. Nedugo nakon Milanovića u Bergamo je konfiniran i smješten u Casa del clero i treći slovenski svećenik, Andrej Grabovšek. Konfinirani svećenici bez dozvole nisu smjeli napustiti bergamsku općinu, a svakog ponedjeljka morali su se javiti u policijsku upravu. Kako su se u konfinaciji u Bergamu nalazile i dvije slovenske i jedna hrvatska obitelj te slovenski učitelj Alojzij Vuga, posjeti i razgovori između “slavenskih zatočenika” ublažavali su tegobnu stvarnost konfinacije.

Sjećajući se konfinacije u Bergamu, informacija o začecima partizanskog pokreta i svog odnosa prema tom pokretu, Milanović napominje kako je od samog početka poticao istarske svećenike da budu u dobrim odnosima s partizanima. Vodstvu NOP-a preporučuje da, ako želi, istinitost ovog njegova navoda može provjeriti kod Zvonimira Brumnića i Kazimira Paića, svećenika koji su uživali povjerenje istarskog NOP-a. ${ }^{70}$ Prema sjećanju Zvonimira Brumnića, tada župnika u Tinjanu, Milanović mu je više puta pisao iz konfinacije: "U pismima je uvijek savjetovao da budemo s partizanima u dobrim odnosima. Oni su prvi organizatori protiv fašizma u Istri. On se nada da će ostvariti san preporoditelja Istre, biskupa Jurja Dobrile, o ravnopravnosti hrvatskog istarskog življa s Talijanima: u crkvi, u uredima, u školi i posvuda. Isticao je velike žrtve partizana koje moramo cijeniti bez obzira na neke ideološke razlike, osobito naglašavane od pojedinih negativnih elemenata. Isticao je nepravednost duha kapitalizma u mnogočemu, te je zagovarao suradnju na narodnom polju. Pisao mi je da i zrno pšenice mora dosta trpjeti, dok ne sazrije i ne postane klas". ${ }^{71}$

Navedeni citat, kao i Milanovićeva tvrdnja o simpatijama prema partizanskom pokretu odmah od njegovih početaka, zahtijeva kritički osvrt i to barem iz dva razloga. Milanović svoj stav iznosi početkom 1944. godine u pismu u kojem se želi opravdati od optužbi koje je vodstvo NOP-a počelo iznositi protiv njega od listopada 1943. godine. S duge, pak, strane Brumnić piše skoro pola stoljeća od događaja koje prikazuje. Iz perspektive trenutka u kojem piše i iz potrebe da opravda Milanovićevu suradnju s novom vlašću, izniklom iz partizanskog pokreta, tu suradnju prebacuje u nešto ranije razdoblje nego što se ona stvarno dogodila. I sam suradnik te vlasti, iako se pred partizanskim prijetnjama morao skloniti u Trst krajem 1944., Brumnić

\footnotetext{
69 Isto, 108.

70 Milanovićevo pismo vodstvu NOP-a, Trst, 2. siječnja 1944. Prema: Dušan Diminić, Istra u partizanskom notesu, Pula 1968., 168.

71 AH IKD, Osobni fond Zvonimira Brumnića, sv. 4, Bilješka o Boži Milanoviću, Lovrečica, 10. prosinca 1988.
} 
je nastojao opravdati i vlastitu kooperativnost prema NOP-u i revolucionarnoj vlasti. ${ }^{72}$ Isto tako, nejasno je tko su ti pojedini negativni elementi o kojima Milanović piše.

Teško je, naime, vjerovati da se oprezni Milanović, koji je k tome pripadao Tajnoj kršćansko-socijalnoj organizaciji, odmah priklonio revolucionarnom pokretu, pa makar mu nacionalni program tog pokreta bio blizak. To tim više što se sve do potkraj rata vjerovalo kako se pitanje priključenja Istre Hrvatskoj može riješiti i mimo NOP-a. U Trstu su tada, naime, osim "kršćansko-socijalne” djelovale i druge dvije organizacije: Narodno vijeće za Goricu i Trst te Hrvatska narodna organizacija za Istru. Sve su se tri organizacije, potpomagane od kraljevske vlade, zalagale za obnovu Kraljevine Jugoslavije kojoj bi se priključila i Istra. ${ }^{73} \mathrm{U}$ prilog navedenom govori jedna Milanovićeva potpuno drukčija ocjena njegova odnosa prema partizanskom pokretu: "Svećenicima, koji su iz Istre obavještavali o tadanjim prilikama i djelovanju partizana pisao sam neka računaju na to da partizanstvo nije nacionalistički nego komunistički pokret, premda pojedini rukovodioci osjećaju vjerojatno, uslijed svojeg odgoja, također nacionalno i da smo mi prema njihovoj novoj naoružanoj organizaciji nemoćni, iako imamo narod uza se". ${ }^{74}$

Partijski aktivisti u okviru svog pojačanog rada na terenu tijekom 1942. nastoje uspostaviti kontakte s istarskim svećenicima narodnjačke orijentacije. Računali su da će njihov uspjeh među “širokim narodnim slojevima” biti kudikamo veći ako ti slojevi vide da se i njihov svećenik priklonio te podržava NOP. Bez obzira na ideološke razlike, znajući za antifašizam i nacionalnu orijentaciju svećenika, računali su da je to dovoljno široka platforma za suradnju. Vođen tim pretpostavkama, Ljubo Drndić, jedan od prvih organizatora NOP-a u Istri, sastao se početkom travnja 1942. sa Zvonimirom Brumnićem, župnikom u Tinjanu. Tom prigodom Drndić ga je pitao za ljude i posebno "za one svećenike koji su provjereni narodni borci i protivnici fašizma”. Prema Drndićevu sjećanju, Brumnić je u taj krug ubrojio i Božu Milanovića spominjući ga "s naročitim poštovanjem”. ${ }^{75}$ Međutim, nije upitno je li Milanović bio narodni borac i protivnik fašizma, nego znači li to da je već tada bio pristaša NOP-a. Samom, pak, Drndiću bilo je jasno da jedan razgovor nije dovoljan da bi se

72 Marcel Krebel, “Zvonimir Brumnić, župnik u Tinjanu 1940.-1945.”, Tinjanski zbornik, gl. ur. Josip Šiklić, Tinjan 2005., 257-258.

73 Stipan Trogrlić, Odnos Katoličke crkve u Istri i jugoslavenske državne vlasti 1945.-1954., Pazin $2008 ., 97$.

74. Božo Milanović, Istra u 20. stoljeću, 2. knjiga, Pazin 1996. (dalje: Istra u 20. stoljeću II), 103.

75 Ljubo Drndić, Orǔ̌je i sloboda Istre, Zagreb 1978., 77. 
uklonile sumnje i nepovjerenje između vodstva NOP-a i svećenika. ${ }^{76}$

Nakon kapitulacije fašističke Italije vlast su u zemlji preuzele njemačke postrojbe. Uz dozvolu njemačkog zapovjednika u Bergamu, Milanović se 11. studenog 1943. vratio u Trst. Biskup Santin odmah ga je angažirao u pružanju pomoći većoj skupini interniraca koja se vraćala u Italiju. Santinu je, naime, papa Pio XII. poslao 200.000 lira kao pomoć povratnicima, među kojima je bilo 60 Dalmatinaca i mnogo Slovenaca političkih zatvorenika. ${ }^{77}$ Prava lavina napada na Milanovića se sručila kad je uz dozvolu njemačkog zapovjednika u Trstu krajem 1943. izdao zidni kalendar za godinu 1944. Traženje dozvole od jedine stvarne vlasti tada u Trstu bilo je dovoljno da ga se optuži za suradnju s Nijemcima, jer kako bi bez te suradnje dobio dozvolu. Osim ove optužbe, Milanovića se teretilo da je inicirao slanje Memoranduma Friedrichu Reineru, njemačkom pokrajinskom zapovjedniku u Trstu u kojem se od njemačke vlasti tražilo pravo pouke u školama na hrvatskom jeziku, uporaba hrvatskog jezika u crkvi, mogućnost povratka kućama pripadnika partizanskih jedinica i amnestija za političke zatvorenike. "Pakirano" mu je održavanje kontakata s predstavnicima Crvenog križa NDH-a u Trstu, veze s vatikanskom diplomacijom i s Ivanom Marijom Čokom, ministrom u izbjegličkoj kraljevskoj vladi. ${ }^{78}$

Unatoč optužbama i napadima, Oblasni narodnooslobodilački odbor (NOO) za Istru odlučio je ipak ne prekidati svaku vezu s Milanovićem i grupom prozivanih svećenika u nadi da će ih se nekako privući NOP-u. ${ }^{79} \mathrm{U}$ Milanovićevom slučaju nije bilo jasno je li mu se time željelo zadržati otvorena vrata za pristup NOP-u ili ga se željelo "namamiti” u Istru i likvidirati. ${ }^{80}$ Znajući da su glave letjele i zbog manjih optužbi od onih izrečenih na njegov račun, umjesto dolaska u Istru, Milanović je na početku 1944. napisao poduže pismo Oblasnom NOO-u u kojem točku po točku (ukupno 9 točaka) odbija sve optužbe na svoj račun.

Obraćanje vodstvu istarskog NOP-a završava, u historiografskim rado-

76 Isto, str. 81.

77 Milanović, Moje uspomene, 113-114.

78 Petar Strčić, "Referat dra Olega Mandića ZAVNOH-u o putovanju Istrom (na početku 1944.)”, Historïjski zbornik, XXI-XXII, 1968-69. (1971.), 433; isti, "Izvještaj Marka Belinića o Istri krajem 1943. godine”, Historïa radničkog pokreta, NOR-a i socijalističke revolucije u Istri, Hrvatskom primorju i Gorskom kotaru, 1, 1978., 273-274; Antun Giron, Prilog proučavanju uloge svećenstva u NOP-u Istre (rukopis, u vlasništvu autora).

79 Diminić, isto, 83.

80 Ivan Grah, Istarska crkva u ratnom vihoru (1943.-1945.), 2. izdanje, Pazin 1998., 8. Josip Šestan (Draguć, 1892. - Zagreb, 1966.), učitelj po zanimanju, prvi predsjednik Oblasnog odbora JNOF-a i istaknuti poslijeratni funkcionar koji se u više navrata susreo s Božom Milanovićem u jednom trenutku mu je priznao da ga je vodstvo NOP-a u Istri preko Brumnića pokušalo nagovoriti da dođe na razgovore u Ježenj (kod Pazina) kako bi ga (Milanovića) likvidirali. Milanović, Istra u 20. stoljeću II, str. 106. 
vima, često citiranim riječima: "Sada nakon rada u 25-godišnjem talijanskom i fašističkom ropstvu, spreman sam sudjelovati s vama u radu za dobro naroda, ako želite, ali uz uvjet da ne gledate na me s nepovjerenjem i da stanete na put klevetama. Ako vam moja suradnja nije poželjna, ja sam pripravan drage volje povući se u posve privatan život i iz zakutka željeti vam uspjeh u radu za sreću našeg naroda u Istri. Ja znam da je doba djelovanja mojega i mojih prijatelja završeno i da se na obzorju pojavila vaša nova sila. Kao što je do sada bilo naše doba, tako sada nastupa vaše doba. A u vrijeme vašeg rada želim da Bog očuva vas i naš narod od nesreće i teških iskušenja”. ${ }^{81}$

Na crti otvorenosti i spremnosti na suradnju s novom političkom i društvenom snagom u Istri, Milanović će ustrajati do kraja života. Ne zato što bi naivno vjerovao kako je postojeće društveno i državno uređenje najbolje od svih mogućih, nego zato što je kao pragmatičan čovjek, uzdižući narodne potrebe iznad uskih staleških interesa, nastojao “iskoristiti” vlast za opće dobro naroda. U tom smislu moguće je shvatiti Milanovićevu kasniju kooperativnost i spremnost na kompromise, što ponekad ostavlja dojam prevelikog sljubljivanja s vlašću.

Tijekom 1944., kako u izvješćima Oblasnog komiteta Komunističke partije Hrvatske (KPH) za Istru i Hrvatsko primorje, tako i u izvješćima Oblasnog NOO-a, Milanović je u više navrata apostrofiran zbog svog protunarodnog djelovanja. Manje-više radilo se o optužbama već ranije iznesenim, a o kojima se Milanović već očitovao u navedenom pismu od 2. siječnja 1944. godine. Najvjerojatniji razlog daljnjih, uglavnom istih, optužbi bio je uzaludan pokušaj da ga se prinudi na ponizno priznanje optužbi i javnu podršku NOP-u. Kad se u toj nakani nije uspjelo, logičan je bio nastavak optužbi i prozivki. Ovdje navodimo kronološkim redom neke od optužbi protiv “popa Milanovića”.

U izvješću Oblasnog komiteta KPH-a za Istru i Hrvatsko primorje od 10. veljače 1944. ponovno je napadnut Milanovićev rad na izdavanju narodnog kalendara i nastojanje oko otvaranja hrvatskih škola, a sve zbog traženja dozvole od njemačkih vlasti. Ništa manje važna nije bila "napomena” kako je samostalno organizirao prikupljanje pomoći za internirce i druge stradalnike te prihvaćanje pomoći ustaškog Crvenog križa. ${ }^{82}$ Samo na prvi pogled bolje je prošao u nešto kasnijem svrstavanju svećenika u 4 grupe. Iza prve grupe, u kojoj su se našli talijanski svećenici otvoreni neprijatelji NOP-a, Milanović

81 Isto, 172 .

82 Izvještaji Oblasnog komiteta KPH-a za Istru, Oblasni komitet KPH za Istru i Hrvatsko primorje Centralnom komitetu KPH, dne. 10. II 1944., Prilog, u: Galiano Labinjan - Dražen Vlahov, "Izvještaj Oblasnog komiteta KPH za Istru 1944.-1945.", Pazinski memorijal, 13, 1984., 463-464. 
i Brumnić su svrstani u drugu grupu, bez kvalifikacije te grupe. Međutim, ako je treća grupa svećenika "kolebljivaca" ili, kako se doslovno kaže, "s opreznim držanjem", a četvrta naših dječaka koji javno i bezrezervno podržavaju NOP, onda je jasno da se Milanović-Brumnićeva grupa tretira kao neprijateljska. ${ }^{83}$ U Izvještaju Oblasnog komiteta KPH-a od 28. srpnja 1944., što se tiče Brumnića i Milanovića, nema nikakvih promjena - zamjera im se dvoličnost: dok razgovaraju s pojedinim rukovodiocima NOP-a "prikazuju se kao prijatelji, dok iza leđa rovare protiv nas". ${ }^{84} \mathrm{U}$ zadnjem izvješću Oblasnog komiteta KPH-a za Istru za godinu 1944. primjetna je samo formalna promjena retorike. Milanoviću i Brumniću se priznaje spremnost da surađuju s NOP-om, no zamjera im se odbijanje ponude da se javno priključe "nama" i da idu u ilegalu ili na oslobođeni teritorij. Na taj način, smatra Izvješće, oni samo otvaraju prostor za svoju staru rabotu na nov način. ${ }^{85}$

Budući da nije dobio nikakav odgovor na svoje pismo, a ne videći ništa lošeg ili protunarodnog u svome radu, Milanović se nakon pisma "oblasnicima" nije povukao u zavjetrinu mirnog privatnog života, nego je istim tempom nastavio na izdavanju hrvatskih knjiga. Vjeran izdavačkoj tradiciji Društva sv. Mohora, nastojao je hrvatskom puku dati u ruke knjigu poučnog, kulturno-vjerskog sadržaja. Tako je krajem 1944. izdao hrvatski zidni kalendar za 1945. godinu, a tijekom 1945. tiskao je Prvu čitanku u 23.000 primjeraka, molitvenik Oče, budi volja tvoja u 50.000 primjeraka te molitvenik Oče naš u 40.000 primjeraka. ${ }^{86}$ Jasno, sve je to bio razlog novih prozivki "popa Milanovića" kao predstavnika domaće reakcije koja, po instrukcijama biskupa Santina, surađuje s međunarodnom reakcijom. I površna analiza izgleda i sadržaja spomenutih kalendara jasno pokazuje da se radilo o tipičnim pučkim kalendarima uobičajenim za izdavačku djelatnost Društva sv. Mohora.

Sam Oleg Mandić, za svog puta po Istri na početku 1944., za kalendar - istina, onaj za godinu 1944., međutim, ništa drukčije nije bilo niti s onim za 1945. godinu - piše: "Nešto po strani stoji pop Milanović, poznati istarski javni radnik (...) Izdao je kalendar za Istru, koji istina ne sadrži nikakve političke propagande, ali je izašao bez odobrenja Oblasnog NOO-a. To je bio jak potez koji mu je pribavio mnogo simpatija, jer je narod objeručke prihvatio

83 Izvješće Oblasnog NOO za Istru od 21. IV. 1944. Prema: Diminić, isto, 101.

84 Izvještaji Oblasnog komiteta KPH-a za Istru, Oblasni komitet KPH za Istru Drugarskom Centralnom komitetu KP Hrvatske, dne 28. VII. 1944., Prilog, u: Labinjan - Vlahov, isto, 494-495.

85 Izvještaji..., Oblasni komitet KPH za Istru Drugarskom Centralnom komitetu KPH, dne 2. XI. 1944., Prilog, u: Labinjan - Vlahov, isto, 539.

86 Milanović, Moje uspomene, 114. 
taj kalendar, koji se ukapčao u prastaru istarsku tradiciju, vidio sam ga skoro u svakoj istarskoj kući u koju sam ušao" ${ }^{87}$

Da i Prva čitanka nije imala nekakvu ideološku podlogu niti je donosila tekstove diskutabilne političke orijentacije, potvrđuje podatak da je Oblasni NOO prihvatio Milanovićev prijedlog da od Društva sv. Mohora otkupi 24.000 primjeraka Čitanke uz cijenu od 18 lira za neuvezane i 22 lire za uvezane primjerke. ${ }^{88}$ Druga je stvar što Milanovićeva molba Predsjedništvu Savezne vlade DFJ-a da se čitanka koristi kao udžbenik u hrvatskim osnovnim školama nije ostvarena, s tim da bi na prve stranice bila stavljena slika maršala Tita. Pretpostavljajući da bi odgovor mogao biti negativan, tražio je da se Čitanka može slobodno prodavati za privatnu upotrebu. ${ }^{89}$ Nešto kasnije potpisani sporazum između Milanovića i predsjednika Oblasnog odbora za Istru Josipa Šestana te predsjednika prosvjetnog odsjeka prof. Ivanušića o Prvoj čitanki bio je jasan dokaz da je Oblasni odbor na mig Savezne vlade prihvatio neke Milanovićeve želje vezane uz Prvu čitanku, a troškove oko uveza, otkupa i dostave Čitanke iz Trsta preuzeo je Oblasni odbor u Labinu. ${ }^{90}$ Međutim, Milanovićeva molba da se Prva čitanka koristi kao udžbenik u hrvatskim školama bila je, u postojećim povijesnim prilikama, nerealna. Komunistička vlast teško je mogla prihvatiti da se kao udžbenik koristi knjiga prožeta kršćanskim svjetonazorom. Zato je Oblasni NOO otkupljene primjerke Prve čitanke prodao tvornici papira kao stari papir samo da ne bi došla, ne samo u škole, nego ni u slobodnu prodaju. ${ }^{91}$

U kontekstu sve češćih napada na istarski kler, od kraja 1944. pa sve do sredine 1945. godine, pojačavaju se napadi i na Božu Milanovića. Radikalizacija i intenzifikacija tih napada bila je posljedica naglog jačanja staljinističkih snaga u NOP-u koje su se, uvjerene u skoru pobjedu, željele osloboditi nepotrebnih suputnika, a u koje su spadali i svećenici. O promjeni retorike i zaokretu u odnosima prema dojučerašnjim saveznicima govori podatak da je samo godinu dana prije (od kraja 1943. do kraja 1944.) na stranicama Glasa Istre izišao niz članaka u kojima se u pozitivnom svjetlu opisivala uloga istarskog hrvatskog svećenstva u tadašnjim zbivanjima. ${ }^{92}$

87 Strčić, "Referat dra Olega Mandića ZAVNOH-u”, 433.

88 AH IKD, OF BM, Prva čitanka II. (bez datuma).

89 Isto, Pismo B. Milanovića u ime "Društva sv. Mohora” Predsjedništvu Savezne vlade, Pazin, 30. IX. 1945.

90 Isto, Zapisnik II., Prva čitanka, Pazin, 1. X. 1945.

91 Milanović, Istra u 20. stoljeću II, 192.

92 Darko Dukovski, "Odnos partizanskih i komunističkih vlasti prema Rimokatoličkoj crkvi i njezinom svećenstvu u Istri od 1943. do 1955.", Dijalog porjesničara-istoričara, Zagreb 2001., 460. 
U svim tim napadima kao crvena nit provlači se optužba da je Milanović sa svojim suradnicima, tražeći i dobivajući dozvole od Nijemaca za svoju izdavačku i namjeravanu prosvjetnu djelatnost (otvaranje hrvatskih škola), nastojao otupiti oštricu NOP-a. U dokazivanju iznesene teze koristi se klasični sofizam: ako se od njemačkih nacista može dobiti nacionalna sloboda, a to potvrđuju dozvole za izdavanje molitvenika, kalendara, čitanke, onda je nepotrebno odlaziti u partizane i podnositi tolike žrtve i stradanja da bi se izborila nacionalna sloboda. U nekima od “prozivki” Milanović je skupa s Brumnićem poimence spomenut, dok je u drugima više nego jasna aluzija na navodni izdajnički put njega i njegovih suradnika. ${ }^{93}$

Najoštriji, prepoznatljivo ideološko-promidžbeno natopljen, napad na Milanovića pojavio se na stranicama Hrvatskog lista iz pera poznatog književnika i publicista Zvane Črnje. Ni manje ni više, Milanović je svrstan u reakcionarnu gamad koja je izdavanjem kalendara i Prve čitanke napokon skinula maske te javno pokazala svoj, do tada, prikriven zločinačko-izdajnički rad. Autor ističe da ni kalendari za 1944. i 1945., a niti početnica, nisu nekakav “nevin” materijal, nego snažno sredstvo neprijateljske promidžbe. U potvrdu iznesenog navodi kako su Milanović i Brumnić pozvali Nijemce i Pavelićeve domobrane da "razbacuju” kalendare po našim selima isto kao što rasturaju po selima njemačke letke i knjigu Ernesta Radetića Iskre pod pepelom. Iz iznesenih premisa izveden je logičan zaključak: "Između istarske reakcionarne gospode i ustaških koljača u Zagrebu ne postoji samo tijesna veza, nego je naša domaća reakcija postala legalna ustaška agentura za Istru i pravo gnijezdo zločinačke perfidnosti ustaštva”. Na kraju, ta tršćanska agentura čiji je čelni čovjek upravo Milanović ima jasan cilj: pretvoriti Istru u krvavo polje bratoubilačkog rata. ${ }^{94}$

Novi žestoki napad na Milanovića i Brumnića dogodio se na sastanku proširenog NOO-a u Poreču 21. svibnja 1945. godine. Dušan Diminić, jedan od istaknutijih istarskih ratnih i poratnih funkcionara, žestoko je napao spomenutu dvojicu svećenika kao "sijače malodušja i razbijače jedinstva”. Spominje se i nekakav Milanović-Brumnićev štab u Trstu, koji je nakon ulaska JA u Trst razbijen. Međutim, do tada su rukovodioci toga štaba, krijući se

93 "Nova izdaja”, Glas Istre (dalje: GI), god III., br. 2 (14. I. 1945.), 2.; "Na izdajničkom putu”, GI, god. III, br. 3 (9. II. 1945.), 2.; "U čemu leži snaga NOP-a u Istri”, GI, god. III, br. 5 (1. III. 1945.), 2. (mjesto izdavanja nije navedeno).

94 “Ustaški zlikovci u Istri”, Hrvatski list, god. II, br. 70 (18. III. 1945. ), str. 2. (mjesto izdavanja nije navedeno). Ovaj tekst je još jedan u nizu onih koji nisu puno vodili računa o činjenicama. Milanović nikad nije održavao veze s ustaškim režimom, u molitvenicima i kalendarima nije bilo nikakvih političkih sadržaja, a po župama su ih, i to dosta uspješno, širili župnici. Usp.: Milanović, Moje uspomene, 114. 
iza svećeničkog talara, sve poduzimali da razbiju NOP. S tim ciljem tiskali su hrvatske knjige, nastojali osnovati hrvatske općine, kontaktirali su s ustaškom vlašću u Zagrebu. Ako se to usporedi s optužbama iznesenim u Črnjinu članku, tada je vrlo vjerojatno da je taj članak Diminiću poslužio kao predložak za sastavljanje svoje liste optužbi. ${ }^{95}$

Ni na javnim skupovima nije zaboravljen protunarodni rad svećenika. Na središnjoj proslavi oslobođenja Istre u pulskoj Areni 12. svibnja 1945., u nazočnosti 30.000 ljudi, predsjednik JNOF-a za Istru Josip Šestan nije mogao ne spomenuti djelovanje reakcije kojoj su se pridružili i “nekoji narodni svećenici”. Poimence su apostrofirani biskup Santin te stalno prozivani dvojac Milanović i Brumnić. Lako je zamisliti kako su na indoktriniranu masu djelovale Šestanove riječi, izrečene u euforičnom ozračju, kako su spomenuta dvojica svećenika i biskup Santin surađivali s okupatorom, slali vjernike u SS trupe i Todt ${ }^{96}$ te govorili da ih partizani vode u propast. ${ }^{97}$

Kad je vodstvu NOP-a postalo jasno kako sudbina Istre nije definitivno riješena na bojnom polju, nego da predstoji diplomatsko-politička borba za njezino sjedinjenje s maticom Hrvatskom, odlučilo je, ovog puta iskrenije, pozvati Milanovića na suradnju. Predstavnici NOP-a Ivan Motika i Dušan Diminić, svjesni Milanovićeva utjecaja među istarskim svećenstvom, ne traže “ultimativno” da dođe u Istru, nego "ponizno” odlaze kod Milanovića u Trst. Neki su taj njihov čin usporedili s odlaskom Henrika IV. u Canossu. ${ }^{98}$ Sporazum između spomenute dvojice čelnika istarskog NOP-a i Milanovića potpisan u Trstu 16. srpnja 1945. otvara novo poglavlje u odnosima između Crkve i nove revolucionarne vlasti. S jedne strane vlast prihvaća pomoći realizaciji nekih, po Milanoviću, strateških ciljeva Crkve u Istri kao što je dodjela zgrade Đačkog doma u Pazinu za potrebe hrvatskog sjemeništa, dozvola za pokretanje vjerskog lista i osnivanje svećeničkog staleškog društva, s druge strane hrvatsko svećenstvo u Istri obvezuje se na "dogovornu izjavu o NOP-u” na sastanku u Pazinu zakazanom za 18. srpnja 1945. "Dogovorna izjava” pretpostavljala je podršku istarskog klera NOP-u u Istri, njegovim ostvarenim

95 Milanović, Istra u 20. stoljeću II, 159-160.

Organizacija "Todt" nazvana je po svom osnivaču Fritzu Todtu, njemačkom inženjeru i nacističkom časniku. Kao poluvojna inženjerijska postrojba u prijeratnom vremenu je sudjelovala u izgradnji autocestovne mreže. Nakon izbijanja Drugog svjetskog rata Todt postaje isključivo vojna organizacija, da bi poslije Todtove pogibije 1942. Albert Speer organizaciju priključio Ministarstvu za naoružanje i ratnu proizvodnju. Tijekom zadnjih dviju ratnih godina za Todt je pod prinudom radilo oko 1,4 milijuna radnika.

97 "Govor predsjednika NOF-e za Istru Josipa Šestana na proslavi oslobođenja u pulskoj areni 12. svibnja 1945.", GI, god. III, br. 38 (Pula, 14. V. 1945.), 1-2.

98 Grah, isto, 8. 
rezultatima i budućim ciljevima. Time počinje novo razdoblje u životu i radu ovog znamenitog Istranina.

\section{Zaključak}

U dugom tršćanskom razdoblju svog djelovanja (1922. - 1945.), prekinutom izbivanjem za vrijeme konfinacije u Bergamu (1941. - 1943.), svećenik Božo Milanović je, svjestan uloge hrvatskih kleričkih i vjerničkih struktura Katoličke crkve u Istri i na nacionalno-političkom i kulturno-prosvjetnom planu, uz redovan pastoralni rad, razvio respektabilno djelovanje, u prvom redu na kulturnoprosvjetnom planu. Ono političko bilo je onemogućeno represivnim mjerama fašističkog režima prema svemu što je odisalo suprotstavljanjem Rapallskom ugovoru, odnosno zalaganjem za priključenje Istre Jugoslaviji. Kao baštinik Dobriline koncepcije narodne sloge zalagao se za suradnju različitih istarskih svjetonazorsko-ideoloških grupacija, a kao pripadnik projugoslavenski orijentirane tajne kršćansko-socijalne organizacije vjerovao je da je za istarske Hrvate jedini izlaz priključenje "slavenskoj braći” u Jugoslaviji. Također je vjerovao da tu povijesnu zadaću može i treba izvršiti jugoslavenska vlada.

Nakon što je 1931. u Italiji zabranjen svaki oblik ne samo političkog, nego i kulturno-prosvjetnog rada koji bi imao "slavensko” obilježje, Milanović će, kroz "Društvo sv. Mohora za Istru” osnovano još 1924. pod "firmom” crkvene bratovštine, nastojati hrvatskom seljaku u Istri pružiti poučno štivo koje je trebalo održavati nacionalni identitet i općehumana načela utemeljena na kršćanskom svjetonazoru. Za svog 21-godišnjeg boravka u Trstu, uz ostale poslove, upravljao je i usmjeravao rad Društva; sve vrijeme obavljao je poslove predsjednika, tajnika i blagajnika. Do 1945. Društvo je izdalo 58 naslova, osim toga, svake je godine izdavalo i pučki kalendar Danica.

Po povratku iz konfinacije nakon kapitulacije Italije, dobiva podrobnije informacije o zamahu i ciljevima NOP-a u Istri. U mjeri u kojoj je pomalo sazrijevala spoznaja kako je NOP jedina relevantna vojno-politička snaga koja je kadra ostvariti san istarskih domoljuba još od 19. st. o sjedinjenju Istre s maticom Hrvatskom, sam Milanović je od kritičnog stava prema NOP-u prelazio na kooperativan. Unatoč brojnim optužbama na njegov račun prihvatio je, bez velikih trauma, ponudu vodstva NOP-a za suradnju na planu zalaganja za opće dobro, tj. sjedinjenje Istre s maticom Hrvatskom. No, tu je suradnju formalizirao potpisivanjem sporazuma tek kad se uvjerio da će biti uvažen i njegov dio nacionalno-vjerskog programa. 


\section{Sažetak}

Božo Milanović, svećenik tadašnje Tršćansko-koparske biskupije, po vlastitom se priznanju odlučio za svećenički poziv uvjeren da će kao svećenik moći najviše koristiti svome narodu. Etiketa "slavenskog nacionaliste", koju je mu je nalijepila austrijska vlast, dobro je došla novoj talijanskoj, najprije vojnoj, potom, formalno, građanskoj te na kraju onoj fašističkoj vlasti, za pritiske i progone. Za nove vlastodršce "slavenski nacionalizam" značio je isto što i protutalijansko, subverzivno djelovanje, čime je bio otvoren lov na Milanovića.

Izložen stalnim pritiscima, prijetnjama, uhićenjima i odvođenjima na sud, nakon konzultacija s biskupom Angelom Bartolomasijem, početkom 1922. odlazi u Trst, uvjeren kako će u velikom gradu manje biti izložen kontroli budnih fašista. Kao župni pomoćnik najprije u župi sv. Ivana, a potom u sv. Antunu Novom, uz redovit pastoralan rad razvio je, također, pozamašan nacionalno-politički i kulturno-prosvjetni rad. U početku se taj rad odvijao kroz istarski Pododbor slovenskog političkog društva Edinost i bio je orijentiran na brigu oko izdavanja novina Pučki prijatelj. lako odgojen u duhu Mahnićeva borbenog katolicizma, predratne istarske ideološko-političke podjele na kršćansko-socijalnu i demokratsko-liberalnu grupu smatrao je u novonastaloj situaciji štetnima za nacionalnu stvar. Zato se vraća Dobrilinoj političkoj koncepciji "narodne sloge" i ostaje joj dosljedno vjeran i kad nije nailazio na razumijevanje istarskih liberala.

Nakon što je 1931. godine zabranjen svaki oblik ne samo političkog, nego i kulturno-prosvjetnog rada s hrvatskim predznakom, Milanović se okreće Društvu sv. Mohora za Istru osnovanom 1924. kao crkvena bratovština (talijanski sodalizio). Pod plaštem bratovštine, kao njezin predsjednik, tajnik i blagajnik, usmjeravao je izdavačku djelatnost kao primarni zadatak Društva sv. Mohora za Istru. Na unutarcrkvenom planu zdušno se zalagao za očuvanje "stečenih prava" na staroslavenski i hrvatski jezik u crkvenim obredima. Pritom se nije libio izraziti svoje neslaganje s jezičnoliturgijskom te općenito unutarcrkvenom nacionalnom politikom svog biskupa Antonija Santina.

Poziv vodstva NOP-a na suradnju nije odmah nekritički prihvatio. Tek kad mu je postalo jasno da je NOP jedina realna snaga koja može ostvariti san generacija istarskih hrvatskih domoljuba o sjedinjenju istre s Hrvatskom, prihvatio je tu suradnju. S druge strane, vodstvo NOP-a, svjesno da će se poslijeratna sudbina Istre rješavati u "diplomatskoj utakmici" te da bi u toj utakmici važnu ulogu moglo imati istarsko hrvatsko svećenstvo, posebno njegov neformalni vođa Milanović, želi pošto-poto realizirati tu suradnju. Sporazum potpisan u Trstu između Milanovića i vodstva NOP-a predstavlja uspješan model kompromisa idejnih protivnika u cilju rješavanja povijesno-sudbinskih državnih i nacionalnih pitanja.

\section{L'opera di rinnovamento nazionale del mons. Božo Milanović nel periodo triestino 1922-1945}

\section{Stipan Trogrlić}

\section{Riassunto}

Božo Milanović, sacerdote di quella che al tempo fu la Diocesi di Trieste e Capodistria, come disse, decise di prendere i voti perché convinto che in questo modo avrebbe potuto essere di maggiore utilità al proprio popolo. L'etichetta di "nazionalista slavo", attribuitagli dal governo austriaco, fu utile al nuovo governo italiano, dapprima quello militare, poi, formalmente, cittadino e infine fascista, per le pressioni e le persecuzioni. Per i nuovi 
detentori di potere, il "nazionalismo slavo" era un sinonimo di attività sovversiva contro l'Italia, il che segnò l'inizio delle persecuzioni di Milanović.

All'inizio del 1922, dopo essere stato esposto a continue pressioni, minacce, arresti e comparizioni in tribunale, consultato il vescovo Angelo Bartolomasi, si spostò a Trieste, convinto che in una città più grande avrebbe potuto evitare l'attento controllo dei fascisti. Da assistente parrocchiale della parrocchia di San Giovanni, e più tardi di Sant'Antonio Nuovo, accanto alla regolare attività pastorale, condusse anche un ampio operato nazional-politico e didattico-culturale. All'inizio svolse tale operato attraverso il Sottocomitato della società politica slovena Edinost e si dedicò alla stampa del giornale Pučki prijatelj. Anche se educato nello spirito del cattolicesimo combattente di Mahnić, considerò che le suddivisioni ideologico-politiche istriane dell'anteguerra, che distinguevano il gruppo cristiano-sociale da quello democratico-liberale, fossero dannose per l'interesse nazionale.

Dopo che nel 1931 fu impedita ogni attività politica, ma anche didattico-culturale legata all'ambito croato, Milanović si rivolse al Sodalizio San Ermacora per l'Istria, fondata nel 1924 come sodalizio ecclesiastico. Sotto il manto del sodalizio, esercitando il ruolo di presidente, segretario e cassiere, diresse l'attività editoriale, compito di primaria importanza per il Sodalizio San Ermacora per l'Istria. A livello interclericale, difese scrupolosamente i "diritti acquisiti" che riguardavano l'uso delle lingue antica slava e croata durante le cerimonie religiose. Nello stesso tempo, non esitò ad esprimere il suo disaccordo con la politica linguistico-liturgica e, in generale, anche quella interclericale nazionale condotta dal suo vescovo Antonio Santin.

Non fu da subito incline ad accettare l'invito alla collaborazione pervenutogli dal comando dell'MPL. Acconsentì appena quando gli fu chiaro che l'MPL era l'unico potere reale che potesse realizzare il sogno di generazioni di patrioti istriani e croati, quello dell'unione dell'Istria alla Croazia. D'altro canto, il comando dell'MPL, consapevole del fatto che il destino dell'Istria postbellica si sarebbe deciso con una "partita diplomatica" e che in essa il clero croato avrebbe potuto svolgere un ruolo importante, e in special modo Milanović, la sua guida non ufficiale, volle realizzare tale collaborazione a tutti i costi. L'accordo tra Milanović ed il comando dell'MPL, firmato a Trieste, rappresenta un modello efficiente di compromesso tra oppositori ideologici, con lo scopo di risolvere fatidiche questioni di storia nazionale e dello stato.

\section{National revival works of Monsignor Božo Milanović during Trieste period 1922-1945}

\section{Stipan Trogrlić}

\section{Summary}

Božo Milanović, who was a priest with the Trieste-Koper Diocese at the time decided, by his own words, to become a priest believing that as a priest he would be of most use to his people. The "Slav nationalist" label he was stuck with by the Austrian government, was welcome in the new Italian, first military then formally, civic and finally fascist government, to perform pressures and prosecution. "Slavic nationalism" was the same as anti-Italian, subversive activity for the new rulers which meant open season on Milanović.

Exposed to constant pressure, threats, arrests and court appearances he leaves for Trieste in 1922, after consulting Bishop Angelo Bartolomasi believing that in the big city he will be less exposed to the control of the ever awake fascists. As assistant pastor, first in 
St. John parish then in St. Anthony New, he also developed massive national-political and cultural-educational work alongside his parish duties. At first, this activity worked through Istrian Subcommittee of Slovenian political society Edinost and was centred on publishing Pučki prijatelj newspapers. Although raised in a spirit of militant Catholicism of Mahnić, he considered pre-war Istrian ideological-political divisions to Christian-social and democratic-liberal groups harmful to the national cause in the new situation. This is why he returned to Dobrila's political concept of "national unity" and remained faithful to it even when faced lack of understanding by Istrian liberals.

After all form of not only political but cultural-educational work with Croatian connotation was banned in 1931 Milanović turned to St. Mohor's Society for Istria, founded as Church fraternity (sodalizio) in 1924. Under the cloak of the fraternity, as its president, secretary and treasurer, he directed the publishing for Istria as the primary task of St. Mohor's Society. Inside Church, he diligently advocated the preservation of the "acquired rights" to old Slavic and Croatian language in Church rites. At the same time he did not hesitate to express his disagreement with liturgy language and generally with national politics within Church promoted by his Bishop, Antonio Santin.

He did not immediately accept the invite for cooperation by the leadership of PLM (People's Liberation Movement) without criticism. Only when it became clear that PLM is the only real force that can fulfil the dream dreamt by generations of Istrian Croatian patriots of uniting Istria with Croatia did he accept the cooperation. On the other hand the leadership of PLM, aware that the post-war destiny of Istria will be resolved in a "diplomatic game" and that Istrian clergy might play an important role in that game, especially their unofficial leader Milanović, wanted to carry out that cooperation by any means. The agreement signed in Trieste between Milanović and the leadership of PLM represents the successful model of compromise between ideological opponents in the common cause of resolving historical-destined state and national questions.

\section{Popis izvora i literature}

\section{Arhivsko gradivo}

Arhiv IKD Juraj Dobrila, osobni fond Bože Milanovića

Arhiv IKD Juraj Dobrila, osobni fond Zvonimira Brumnića

\section{Novine}

Glas Istre

Hrvatski list

Pučki prijatelj

\section{Literatura}

Čermelj, Lavo, Il vescovo Antonio Santin e gli Sloveni e Croati delle diocesi di Fiume e Trieste e Capodistria, Ljubljana: Inštitut za narodnostna vprašanja pri Univerzi v Ljubljani, 1953. Diminić, Dušan, Istra u partizanskom notesu, Pula: Istarska naklada, 1986. 
Drndić, Ljubo, Oružje i sloboda Istre, Zagreb: Školska knjiga / Glas Istre, 1978.

Dukovski, Darko, "Odnos partizanskih i komunističkih vlasti prema Rimokatoličkoj crkvi i njezinom svećenstvu u Istri 1943.-1945.", Dijalog povjesničara - istoričara, 3, zbornik radova, ur. Hans-Georg Fleck i Igor Graovac, Zagreb: Friedrich Neumann Stiftung, 2001. 457-472.

Giron, Antun, Prilog proučavanju uloge svećenstva u NOP-u Istre (rukopis, u vlasništvu autora).

Grah, Ivan, Istarska crkva u ratnom vihoru (1943.-1945.), 2. izdanje, Pazin: IKD Juraj Dobrila, 1998.

Krebel, Marcel, "Zvonimir Brumnić, župnik u Tinjanu 1940.-1945.", u: Tinjanski zbornik, ur. Josip Šiklić, Tinjan: Matica hrvatska Pazin / Poglavarstvo Općine Tinjan, 2005., 255-260.

Labinjan, Galiano - Vlahov, Dražen, "Izvještaj Oblasnog komiteta KPH za Istru 1944.1945.", Pazinski memorijal, 13, 1984., 453-556.

Milanović, Božo, Hrvatski narodni preporod u Istri, knjiga II., Pazin: IKD sv. Ćirila i Metoda, 1973.

Milanović, Božo, Istra u 20. stoljeću, I. knjiga, Pazin: IKD Juraj Dobrila, 1992.

Milanović, Božo, Istra u 20. stoljeću, II. knjiga, Pazin: "Josip Turčinović", 1996.

Milanović, Božo, Moje uspomene (1900 - 1976), Pazin: IKD sv. Ćirila i Metoda / Kršćanska sadašnjost, 1976

Strčić, Petar, "Izvještaj Marka Belinića o Istri krajem 1943. godine", Historija radničkog pokreta, NOR-a i socijalističke revolucije u Istri, Hrvatskom primorju i Gorskom kotaru, 1, 1978., 257-281.

Strčić, Petar, "Referat dra Olega Mandića ZAVNOH-u o putovanju Istrom (na početku 1944.)", Historijski zbornik, XXI-XXII, 1968-69. (izd. 1971.), 419-453.

Trogrlić, Stipan, "Porečko-pulska biskupija u vrijeme biskupa Ivana Flappa (1885.-1912.)", Problemi sjevernog Jadrana, 8, 2003., 73-106.

Trogrlić, Stipan, Odnos Katoličke crkve u Istri i jugoslavenske državne vlasti 1945.-1954., Pazin: "Josip Turčinović", 2008. 
